\title{
Overlitigating Corporate Fraud: An Empirical Examination
}

\author{
Jessica M. Erickson*
}

\begin{abstract}
Corporate law leaves no stone unturned when it comes to litigating corporate fraud. The legal system has developed a remarkable array of litigation options - shareholder derivative suits, securities class actions, SEC enforcement actions, even criminal prosecutions-all aimed at preventing the next corporate scandal. Scholars have long assumed that these different lawsuits offer different avenues for deterring the masterminds of corporate fraud-yet this assumption has gone untested in the legal literature. This Article aims to fill that gap through the first empirical examination of the broader world of corporate fraud litigation. Analyzing over 700 lawsuits, the study reveals that these lawsuits do not target different types of corporate wrongs. Instead these lawsuits too often target the same alleged misconduct, the same defendants, and the same corporate coffers. The data also demonstrate that certain types of lawsuits consistently outperform others, creating a litigation hierarchy within corporate law. These findings raise critical questions about traditional theories of deterrence, suggesting that more may not always be better when it comes to combating corporate fraud. The Article then brings these empirical insights to bear in developing a new framework for more targeted deterrence of corporate fraud.
\end{abstract}

INTRODUCTION.

I. Methodology

A. STUDY PARAMETERS.

* Associate Professor, University of Richmond School of Law. B.A., Amherst College; J.D., Harvard Law School. The research conducted for this Article was supported by a research grant from the American Bar Association ("ABA") Section of Litigation; however, the views expressed here are not intended to represent ABA positions or policies. This Article benefited from suggestions made at the Vanderbilt Law \& Business Conference, the Law \& Society Annual Conference, and the Virginia Junior Faculty Forum. I want to thank Bernard Black, Elizabeth Burch, Stephen Choi, Jill Fisch, Jim Gibson, Sean Griffith, Lee Harris, Corinna Lain, Kristen Osenga, Jack Preis, Adam Pritchard, Tony Rickey, and Noah Sachs for their helpful comments and thoughts in developing this Article. I also want to thank Shan Xu for his assistance with the data analysis. 


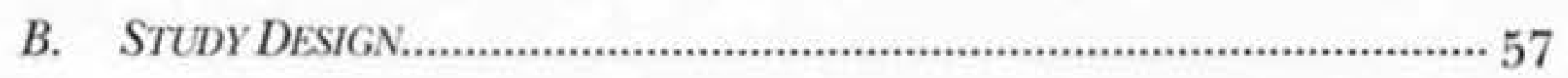

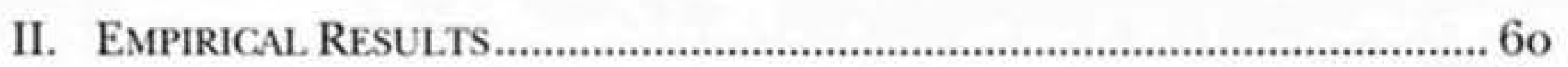

A. THE PARALILL. WORLD OF CORPORATE FRAUD LITIGATION .................. 61

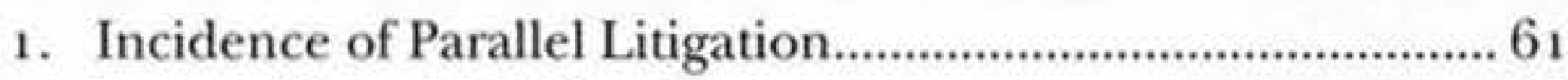

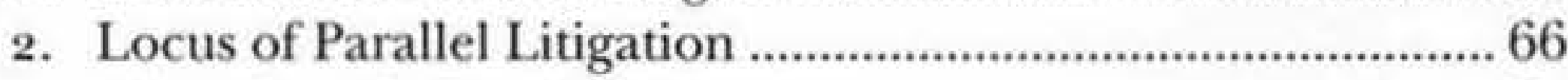

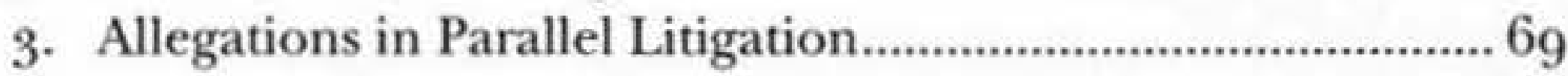

B. SHAREHOLDER DERIVATIVE SUITS AS PARALIEL LITIGATION............... $7^{2}$

1. Comparing Filing Dates....................................................... 72

2. Comparing Defendants ........................................................... 74

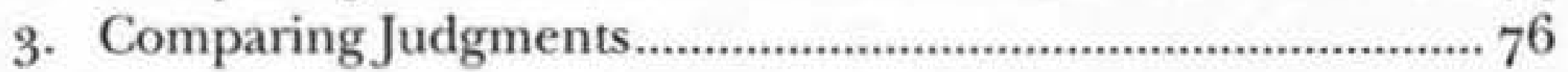

III. IMPLICATIONS: TOWARD TARGETED DETERRENCE OF CORPORATE FRAUD IN SHAREHOLDER DERIVATIVE LITIGATION .................................. 81

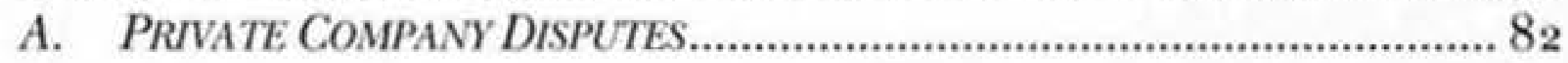

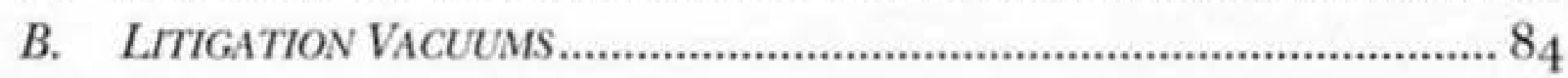

C. THE CASE OF CORPORATE OUTSIDERS ................................................. 88

D. THE ROLE OF CORPORATE NORMS ….................................................. 92

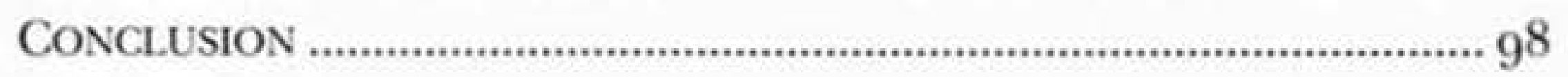

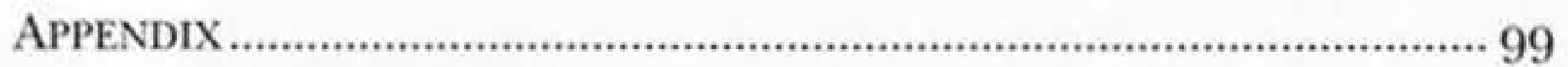




\section{INTRODUCTION}

In the wake of the unprecedented meltdown in the financial markets, few would argue that the law should curtail available avenues to combat corporate fraud. Scholars and politicians alike have turned to legislationand litigation-to prevent future financial catastrophe.' Congress responded to fiscal duplicity in the mortgage industry, for example, by passing landmark legislation that overhauled regulation of financial institutions and made it easier to sue credit rating agencies. ${ }^{2}$ The federal government similarly reacted to the sweeping fraud orchestrated by Bernie Madoff by giving the Securities and Exchange Commission ("SEC") a wide array of new tools to bring corporate wrongdoers to justice. 3 When it comes to combating corporate fraud, conventional wisdom holds that more is better.

The reason is simple: Corporate managers, like burglars or tax evaders, are less likely to engage in misconduct if they know that this misconduct could expose them to legal liability. This deterrent potential has been used to justify nearly every type of corporate lawsuit.4 Scholars have even defended oft-criticized types of corporate fraud lawsuits, such as securities class actions and shareholder derivative suits, on the ground that these lawsuits help deter corporate misconduct. ${ }^{5}$

Yet this simple story masks the complex reality of corporate fraud litigation. Corporate law differs from criminal law or tax law in a fundamental way-corporate law uses multiple means to punish the same conduct. Take the example of Goldman Sachs Group, Inc. Last year,

1. See, e.g., S. RE.P. No, 111-10, at 3 (2009) ("To make sure this kind of collapse cannot happen again, we must reinvigorate our anti-fraud measures and give law enforcement agencies the tools and resources they need to root out fraud so that it can never again place our financial system at risk."); John C. Coffee, Jr. \& Hillary A. Sale, Redesigning the SEC: Does the Treasury Have a Better Idea?, 95 VA. L. REv. 707, 717 (2009) (arguing that the relaxation of traditionally aggressive antifraud laws was a "leading cause" of the current financial crisis).

2. See Dodd-Frank Wall Street Reform and Consumer Protection Act, Pub. L. No. 111$203, \$ 933,124$ Stat. $1376,188_{3}-84$ (2010) (to be codified at 15 U.S.C. $\$ 78 \mathrm{u}-4$ (b) (2) (B)).

3. See id. passim; Zachary A. Goldfarb, As Financial Reform Becomes Law, SEC Emerges with New Powers and Duties, WASH. POST, July 22, 2010, http://www.washingtonpost.com/wp$\mathrm{dyn} /$ content/article/2010/07/21/AR201007210639o.html (stating that the Dodd-Frank Act requires the SEC to issue nearly one hundred new regulations).

4. See Tom Baker \& Sean J. Griffith, How the Merits Matter: Directors and Officers Insurance and Securities Settlements, 157 U. PA. L. REV. 755. 762 (2009) ("Scholars customarily treat deterrence as the principal objective of civil damages in corporate and securities litigation."); John C. Coffee, Jr., Reforming the Securities Class Action: An Essay on Deterrence and Its Implementation, 106 CoLUM. L. REV. ${ }_{534}$, 1556-66 (2006).

5. See, e.g., Kenneth B. Davis, Jr., The Forgotten Derivative Suit, 61 VAND. L. REv. $3^{87}, 405$ $(2008)$ (stating that "justification for the derivative suit" increasingly relies "on the suit's deterrent role"); Carol B. Swanson, Juggling Shareholder Rights and Strike Suits in Derivative Litigation: The ALI Drops the Ball, 77 MINN. L. REV. 1339, 1346 (1993); see also infra notes 9-10 (addressing the role of deterrence in securities class actions). 
government investigators raised questions about mortgage securities sold to investors as the economy started to unravel. ${ }^{6}$ Goldman Sachs and its executives were quickly hit with charges filed by the SEC, a sweeping securities class action, and shareholder derivative suits filed in state and federal court.7 These lawsuits are a high-profile example of the world of parallel corporate fraud litigation-a world in which the same allegations of corporate fraud can give rise to different lawsuits based on different theories of liability.

Parallel litigation is not limited to corporate law. In the months since the BP oil spill, for example, BP has been besieged with lawsuits filed by commercial fishermen, business owners, and residents of the Gulf of Mexico, all seeking compensation for the financial losses they have suffered. ${ }^{8}$ Parallel litigation in other areas of the law typically reflects multiple claims for compensation. What makes corporate fraud litigation unique, however, is that its primary goal is not to provide compensation to different groups of victims. 9 Its primary purpose is to deter. ${ }^{10}$

6. Sec Goldman Sachs Grp., Inc., Current Report (Form 8-K) (Apr. 16, 2010), available at http://www2.goldmansachs.com/our-firm/investors/financials/archived/8k/pdf-attachments/ 4-16-8k-doc.pdf.

7. See Complaint, SEC v. Goldman Sachs \& Co., No. 1:10CVoz229 (S.D.N.Y. June 10. 2011 ), 2010 WL 1508202 (alleging violations of the federal securities laws); Memorandum of Law in Support of Tikva Bochner's Motion To Consolidate. Appoint Tikva Bochner Lead Plaintiff, and Approve Lead Plaintiff's Choice of Counsel, Richman v. Goldman Sachs Grp., Inc., 274 F.R.D. 473 (S.D.N.Y. 2010) (No. 1:10-cv-03461 (PAC)), 2010 WL 3055218 (requesting consolidation of numerous parallel securities class actions); Goldman Sachs Grp., Inc., Current Report (Form 8-K) (May 3, 2010), available at http://www2.goldmansachs.com/ our-firm/investors/financials/archived/8k/pdf-attachments/05-03-10-8k-doc.pdf (disclosing filing of shareholder derivative suits).

8. See Melinda Arbuckle, Case Chart, BP LrTG., http://sites.google.com/site/ bplitigation/home/case-chart (last visited Aug. 27, 2011) (listing more than 250 suits that were filed against BP PLC relating to the oil spill between April 20, 2010 and June 3, 2010).

9. Coffee \& Sale, supra note 1 , at 762 ("[C]ompensation is only minimally achieved in today's enforcement and litigation world, and arguably properly so."); Merritt B. Fox, Civil Liability and Mandatory Disclosure, 109 Col.uM. L. REv. 237, 281 (2009) (arguing that "the compensation justification for a cause of action against the issuer for a misstatement in a disclosure filing is very weak, particularly given the high transaction costs associated with securities litigation"); Amanda Rose, Reforming Securities Litigation Reform: Restructuring the Relationship Between Public and Private Enforcement of Rule 10b-5, 108 COLUM. L. REV. 1301, 1314 (2008) ("[M]ost commentators now agree that the prototypical Rule $10 b-5$ class action (i.e., one brought against a nontrading corporation for its officer's fraud-on-the-market) cannot be defended on compensatory grounds.").

10. This point enjoys nearly universal acceptance among corporate law scholars. See Coffee, supra note 4 , at 1536 (arguing that compensation is "unobtainable" in securities class actions and that "deterrence ... is the only rationale that can justify the significant costs-both public and private- that securities class actions impose on investors and the judiciary"); James D. Cox \& Randall S. Thomas, Letting Billions Slip Through Your Fingers: Empirical Evidence and Legal Implications of the Failure of Financial Institutions To Participate in Securities Class Action Settlements, 58 STAN. L. REV. $4^{11}, 4^{14}(2005)$ (arguing that deterrence is "the more persuasive rationale" for securities class actions); A.C. Pritchard, Markets as Monitors: A Proposal To Replace 
The phenomenon of parallel litigation complicates this picture considerably. It is no longer enough to say that litigation is good because it deters corporate fraud. The focus must instead be on whether and how specific types of lawsuits deter corporate fraud, given the panoply of litigation options. When a corporate executive faces the threat of jail time in a criminal proceeding or the possibility of multimillion-dollar sanctions in a securities class action, for example, what additional deterrence does a shareholder derivative suit provide?

Thus far, there is little corporate law scholarship addressing the interplay between different types of corporate fraud lawsuits." Nor has it examined the impact of these parallel lawsuits on traditional justifications for corporate fraud litigation. This Article aims to fill that gap by presenting the first empirical examination of the world of parallel corporate fraud litigation. The study tracks approximately 700 lawsuits over a five-year period against more than 160 companies accused of corporate misconduct. It traces all of the litigation arising out of the alleged misconduct, including shareholder derivative suits, securities class actions, enforcement actions filed by the SEC, criminal investigations, and ERISA class actions.

Within this array of lawsuits, the study focuses on one in particularshareholder derivative suits-for two reasons. First, shareholder derivative suits are among the most common type of private corporate fraud lawsuit, outnumbering securities class actions and many other types of litigation. ${ }^{12}$ Second, shareholder derivative suits are the most maligned weapon in the law's arsenal to fight corporate malfeasance. ${ }^{13}$ These points make shareholder derivative suits the ideal starting point in examining the broader world of corporate fraud litigation.

From this focused investigation, three key findings emerge. First, the traditional roles assigned to different types of corporate litigation have all but disappeared. Scholars have long believed that securities class actions and government enforcement suits target fraud, while shareholder derivative

Class Actions with Exchanges as Securities Fraud Enforcers, 85 VA. L. REV. 925, 947 (1999) ("Deterrence, not compensation, is the answer to the problems of loss of liquidity, reduced managerial accountability, and distorted capital allocation."); supra notes $4-5$.

11. There are a few studies examining the kinds of corporate fraud lawsuits. See, e.g., James D. Cox et al., SEC Enforcement Heuristics: An Empirical Inquiry, 53 DUKE. L.J. 737 (2003).

12. See Jessica Erickson, Corporate Governance in the Courtroom: An Empirical Analysis, $5^{1}$ WM. \& MARY L. REV. 1749, 1762-63 (2010).

13. Robert B. Thompson \& Randall S. Thomas, The Public and Private Faces of Derivative Lawsuits, 57 VAND. L. REV. 1747 (2004); see also Roberta Romano, The Shareholder Suit: Litigation Without Foundation?, 7 J.L. ECON. \& ORG. 55, 84 (1991) (stating that empirical evidence on shareholder derivative suits "support[s] the conclusion that shareholder litigation is a weak, if not ineffective, instrument of corporate governance"); STEPHEN M. BAINBRIDGE, CORPORATION LAW AND ECONOMICS 403 (2002) ("A radical solution would be elimination of derivative litigation.... [D]erivative litigation appears to have little if any beneficial accountability effects. On the other side of the equation, [it] is a high cost constraint and infringement upon the board's authority."). 
suits target other types of corporate wrongdoing. ${ }^{14}$ Contrary to this conventional account, however, different types of corporate lawsuits do not target different types of corporate wrongs. Corporate litigation is instead focused on a single target-fraud.

Second, corporate fraud litigation rarely occurs in a single courtroom. Parallel litigation is the norm not only in the high-profile scandals that grace the front pages of the Wall Street Journal, but also in the run-of-the-mill corporate fraud cases that never reach the newspapers. Approximately $95 \%$ of the shareholder derivative suits filed on behalf of public companies in this study were accompanied by at least one parallel lawsuit. Approximately $80 \%$ of the public company suits were accompanied by two or more parallel lawsuits.

Third, not all corporate fraud litigation is created equal. The study uncovers a litigation hierarchy in which certain types of lawsuits consistently outperform others. Government investigations rank at the top of this hierarchy, dispensing swift justice against the masterminds of corporate fraud. Securities class actions come second. These lawsuits often lead to multimillion-dollar settlements that nonetheless lack a strong deterrent punch because the funds typically come from corporate bank accounts, not from the individual wrongdoers. Shareholder derivative suits rank a distant third, often ending with settlements composed of cosmetic corporate governance reforms that offer little substantive value. The data suggest that while shareholder derivative suits are the most common type of corporate fraud lawsuit, they are also the least effective. In short, we may be overlitigating corporate fraud.

This Article proceeds in three parts. Part I sets out the design and methodology of the study. Part II presents the empirical results, revealing that a single act of corporate fraud often sparks multiple lawsuits targeting the same alleged misconduct, the same defendants, and the same corporate coffers. Part III builds on these empirical data by presenting a framework for more targeted deterrence of corporate fraud, one that views shareholder derivative suits within the larger landscape of litigation. Corporate law scholarship can no longer afford to view these lawsuits in isolation. In the end, nothing happens in a vacuum, not even corporate fraud.

\section{METHODOLOGY}

This Part presents the methodology of the study. First, it provides the study parameters, describing the various litigation options available in the wake of corporate misconduct. Second, it presents the study design, which is based on the "gold standard" in litigation research-an in-depth

14. See infra notes $8_{2}-8_{3}$ and accompanying text. 
examination of case records rather than published judicial decisions. ${ }^{15}$ This approach allows for more reliable conclusions about the role of litigation in deterring corporate fraud.

\section{A. STUDY PARAMETERS}

Plaintiffs can file a wide array of lawsuits in the wake of alleged corporate misconduct. To examine the interplay between these lawsuits, the study parameters included ten different types of corporate litigation, ${ }^{16}$ while focusing on the most prevalent among them: shareholder derivative suits, securities class actions, and government enforcement actions. In this section, I discuss the panoply of litigation options available to combat corporate fraud, providing a foundation for the analysis that follows.

Shareholder derivative suits are the procedural mechanism to enforce state fiduciary duty law. ${ }^{17}$ In a derivative suit, the corporation is the functional plaintiff-the real party in interest ${ }^{18}$ - and the allegations are typically that the corporation's current or former officers and directors breached their fiduciary duties to the corporation. ${ }^{19}$ These allegations can run the gamut from traditional allegations of self-dealing and usurpation of corporate opportunities to allegations of corporate fraud and financial deceit. Despite the fact that a derivative suit is brought in the corporation's name, the corporation's role is limited because shareholders, who I will call "derivative plaintiffs," file these suits on behalf of corporations. ${ }^{20}$ The law gives shareholders this power because corporate officers and directors, who normally decide whether corporations should file lawsuits, are often

15. Margo Schlanger \& Denise Lieberman, Using Court Records for Research, Teaching, and Policymaking: The Civil Rights Litigation Clearinghouse, 75 U. MO. KAN. CrTy L. REV. 155, 163 (2006). A number of researchers have used a similar approach in examining other areas of the law. See, e.g. James D. Cox et al., There Are Plaintiffs and ... There Are Plaintiffs: An Empirical Analysis of Securities Class Action Settlements, 61 VAND. L. REV. 355 (2008); David A. Hoffman et al., Docketology, District Courts, and Doctrine, 85 WASH. U. L. REV. 681 (2007); Margo Schlanger, Inmate Litigation, 116 HARV. L. REV. 1555 (2003); Ronald F. Wright, Trial Distortion and the End of Innocence in Federal Criminal Justice, 154 U. PA. L. REV. 79 (2005).

16. These lawsuits included: (1) federal shareholder derivative suits, (2) state shareholder derivative suits, (3) securities class actions, (4) SEC investigations and lawsuits against the company, (5) SEC lawsuits against the individual defendants, (6) criminal investigations and lawsuits against the company, (7) criminal lawsuits against the individual defendants, (8) other government investigations of the company, (9) other government investigations of the individual defendants, and (10) other parallel litigation. There are other types of corporate litigation as well, such as veil piercing lawsuits, breach of contract suits, and acquisition-oriented class actions. These lawsuits are included in the study only to the extent that they accompany a parallel shareholder derivative suit.

17. See, e.g., In re Fuqua Indus., Inc. S'holder Litig., 752 A.2d 126, 133 (Del. Ch. 1999).

18. In re MAXXAM, Inc./Federated Dev. S'holders Litig., 698 A.2d 949. 956 (Del. Ch. 1996).

19. See Erickson, supra note 12, at 1773-78.

20. Schoon v. Smith, 953 A.2d 196, 202 (Del. 2008). 
implicated in the alleged wrongdoing and cannot be trusted to make unbiased decisions regarding the merits of these suits. ${ }^{21}$

In contrast, securities class actions are brought under the federal securities laws. In securities class actions, shareholders typically sue the corporation and the corporation's officers and directors, alleging that the defendants lied to the market by making false or misleading statements about the corporation's business model or financial results. ${ }^{22}$ Any recovery is distributed to the class. The federal securities laws vest the federal courts with exclusive jurisdiction over many of these claims. ${ }^{23}$

Finally, the government is empowered to bring civil or criminal charges against corporate wrongdoers. The SEC can file civil enforcement actions against corporations or executives who make false or misleading statements to the investing public or aid and abet those who make the offending statements. ${ }^{24}$ The Department of Justice ("DOJ") or state authorities can also file criminal charges against those who engage in certain types of corporate wrongdoing. ${ }^{25}$ These criminal proceedings can target either the corporation itself or the individuals who manage the corporation..$^{26}$

In addition to these predominant forms of corporate litigation, there are also a number of other suits that get less attention in the press but that can pack a significant punch. Employees can often file ERISA class actions, ${ }^{27}$ alleging that the managers of employee benefit plans breached their fiduciary duties by causing the plan to purchase company stock as an investment option when they knew or should have known that the stock price was artificially inflated. ${ }^{28}$ Other private litigants may also file lawsuits. Customers, for example, may file consumer class actions, alleging that a product was defective or that the company's representations regarding the product were false. Partners or affiliates of the target company may allege

21. Aronson v. Lewis, 473 A.2d 805,811 (Del. 1984).

22. See, e.g., In re NAHC, Inc. Sec. Litig., 306 F.3d 1314, 1330 (3d Cir. 2002).

23. See 15 U.S.C. $\$ 78$ aa (2006) (amended 2010 ).

24. See 15 U.S.C. $\$ 78 \mathrm{t}$ (e) (amended 2010) (authorizing the SEC to bring aiding and abetting charges); Aaron v. SEC, 446 U.S. $680,688-89$ (198o) (outlining the SEC's authority). The SEC also has additional enforcement powers that are outside the scope of this study.

25. The DOJ, for example, can bring a criminal action directly under section 10 (b) of the Securities Exchange Act of 1934 . See 15 U.S.C. $\$ 78 j(b)$ (amended 2010 ). The DOJ may also be able to attack such conduct through laws prohibiting wire fraud, mail fraud, money laundering, or similar statutes. See 18 U.S.C. $\$ 134^{2} ;$ id. $\$ 1343$ (amended 2008); id. $\$ 1957$ (amended 2009).

26. See, e.g., Jennifer Arlen \& Reinier Kraakman, Controlling Corporate Misconduct: An Analysis of Corporate Liability Regimes, 72 N.Y.U. L. REV. $687,69^{2}$ (1997).

27. ERISA is the Employee Retirement Income Security Act of 1974, Pub. L. No. 93-4o6. 88 Stat. 829 (codified as amended at 29 U.S.C. $\$ \S 1001-1461(2006)$ ).

28. See In re Unisys Corp. Retiree Med. Benefits ERISA Litig., 579 F.3d 220, 228 (3d Cir. 2009) (holding that "an ERISA fiduciary may not, in the performance of its duties, "materially mislead those to whom the duties of loyalty and prudence are owed" (quoting Adams v. Freedom Forge Corp., 204 F.3d 475, $49^{2}$ (3d Cir. 2000))). 
that the company breached relevant contracts or duties by engaging in the challenged activities. Finally, there may be other government investigations launched by the Internal Revenue Service, Department of Labor, or even Congress. As the figure below demonstrates, there is no shortage of litigation that can be filed in the wake of corporate fraud.

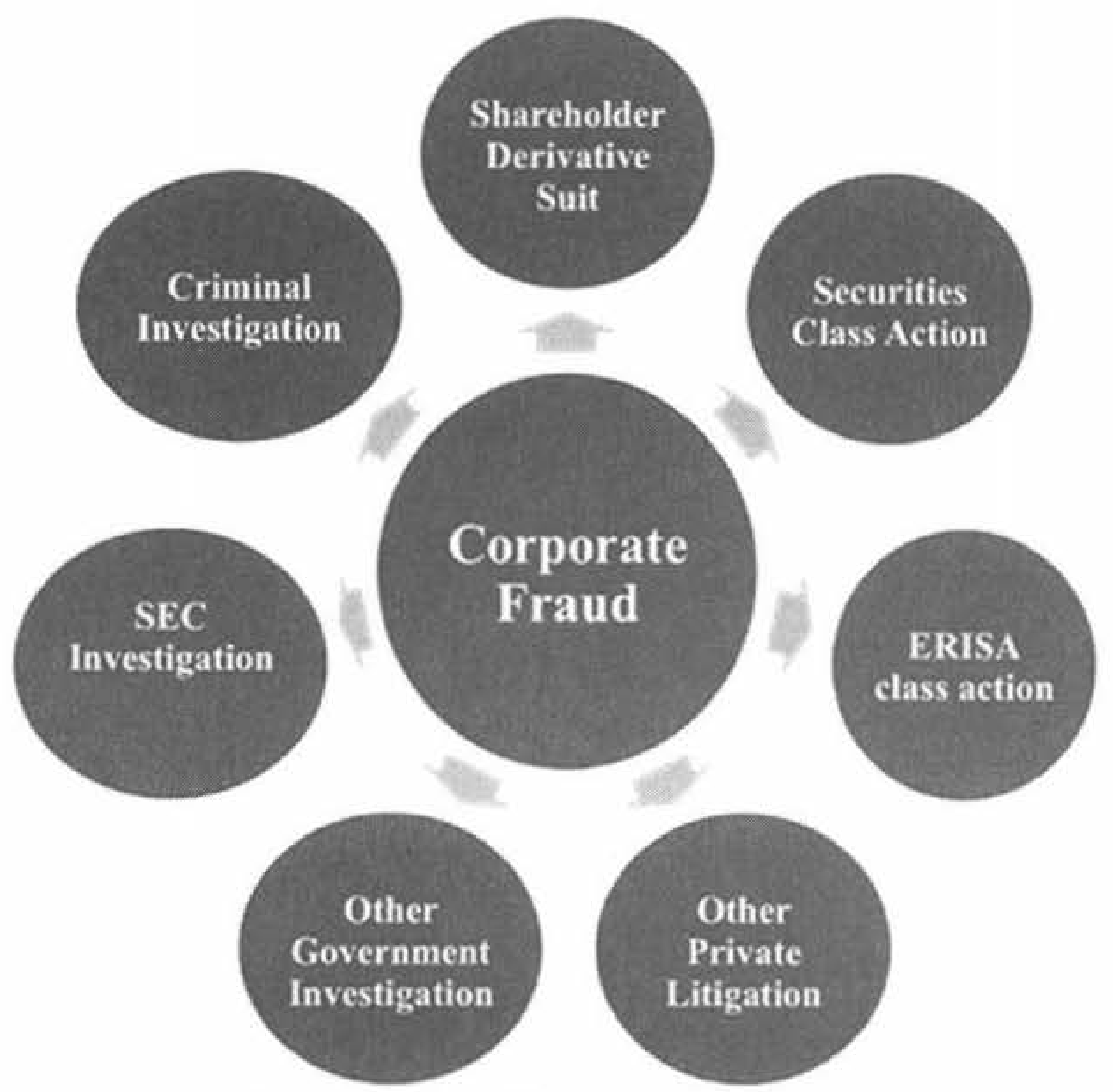

Figure 1. Types of Corporate Fraud Lawsuits

This study examines the interplay between these various lawsuits, focusing specifically on the role of shareholder derivative suits within this larger landscape of corporate fraud litigation.

\section{B. STUDY DESIGN}

The study analyzed more than 160 corporations accused of fraud or other malfeasance. These companies were all named in shareholder derivative suits filed in federal court. ${ }^{29}$ As discussed above, this study focused on the role of shareholder derivative suits within the broader world of

29. For more detail regarding these shareholder derivative suits and the methodology used to identify them, see Erickson, supra note 12 , at 1773-78. 
corporate fraud litigation because these suits are the most common-and most criticized-type of corporate fraud lawsuit. $3^{\circ}$

I first used the Dockets database in Westlaw to identify the shareholder derivative suits.3' The search was designed to identify all shareholder derivative suits filed in federal court during the relevant time period. $3^{2}$ I then accessed the entire case records for these suits through the Public Access for Court Electronic Records ("PACER") system maintained by the federal courts. 33 This method is consistent with emerging best practices in litigation research, which recognizes that litigation research should be based on an understanding of all cases, not simply reported decisions in Westlaw or Lexis. ${ }^{4}$ As scholars have demonstrated, reported decisions suffer from a selection bias because fewer than $5 \%$ of judicial decisions are available through these databases. 35 The study attempts to identify all shareholder derivative suits filed in federal court during the relevant time period, not just a selection of reported decisions.

For each shareholder derivative suit, I determined the underlying event or series of events at issue. The suits typically arose out of a discrete event such as an accounting error or an alleged misstatement to the market. ${ }^{6} \mathrm{I}$ then attempted to trace all of the litigation arising out of this event, including securities class actions, enforcement actions filed by the SEC,

30. See supra notes $12-13$.

31. The search used in the Westlaw Dockets database was "derivativ! \& da(aft $6 / 30 / 2005$ $\&$ bef $7 / 1 / 2006)^{*}$.

32. The study tracked all derivative suits filed between July 1, 2005, and June 30,2006 . These suits were tracked from the time of filing through July 2010 , allowing the study to capture approximately five years of litigation activity. The start date was chosen because electronic case filing was not mandated in all federal district courts until fairly recently and many case records are not available prior to that time.

33. PUB. ACCESS TO COURT ELEC. RECORDS, http://www.pacer.gov/cgi-bin/links.pl (last visited Aug. 27, 2011).

34. See Christina L. Boyd \& David A. Hoffman, Disputing Limited Liability, 104 Nw. U. L. REV. 853,856 (2010) (stating that the analysis of dockets and other litigation records is a "new and robust form of legal realism"); Pauline T. Kim et al., How Should We Study District Judge Decision-Making?, 29 WASH. U. J.L. \& POL'Y 83, 103 (2009) ("We propose that, rather than relying on opinions, scholars use dockets and the other case documents available on PACER as data sources for studying district judge decision making. By looking at dockets, researchers can capture all of the critical decisions in a case, thereby avoiding the problems of selection bias introduced by relying only on opinions or published opinions.").

35. See Hoffman et al., supra note 15 , at 710 ("Overall, of the 5.736 judicial actions we recorded, only $178-3 \%$-came accompanied by opinions.").

36. As Professor John Coffee noted many years ago, "dramatic, highly visible events underlie most securities class actions and derivative suits," John C. Coffee, Jr., Understanding the Plaintiffs Altome: The Implications of Economic Theory for Private Enforcement of Law Through Class and Derivative Actions, 86 COL.UM. L. REv, 669,682 (1986), and the cases in this study were no different. A smaller number of the derivative suits in the study related to more than one event. In these cases, I traced all of the litigation arising out of any significant events or series of events at issue in the derivative suit. 
criminal investigations, other regulatory actions, ERISA class actions, consumer class actions, and other parallel litigation. 37

I used several methods to identify these lawsuits. First, I reviewed the company's public filings because public companies are required to disclose all material litigation. $3^{8}$ Second, I searched the websites of the SEC and the DOJ because both agencies typically issue press releases, as well as related case documents, when they file enforcement actions. Third, I searched the Stanford Securities Class Action Clearinghouse, 39 which tracks securities class actions filed across the country. Fourth, I reviewed the case filings from the underlying derivative suits because these filings often referred to parallel litigation. Fifth, I performed numerous Internet searches to locate additional cases that were not identified through the above sources. Finally, I made Freedom of Information Act requests in a few cases where relevant documents were not otherwise available.

I then reviewed the entire case records for each lawsuit. $4^{\circ}$ Data from the case records were coded into a specially designed database. This coding included a wide range of variables, including the defendants named in the suits, the types of claims, the relative timing of the suits, and the outcome of the suits. Finally, I collected additional data regarding the target corporations, including the industry, market capitalization, $4^{1}$ whether the company restated its financial results following the alleged events, and whether the company conducted a related internal investigation..$^{2}$ Overall, this study tracks approximately 700 cases and government investigations over approximately five years. 43

37. This study included only those cases in which there was a significant overlap in the events at issue. In a few instances, there was only a slight overlap, and in these instances, I did not code the cases as related.

38. See 17 C.F.R. $\$ 229.103$ (2011).

39. Stanford Law Sch. \& Cornerstone Research, StAnford SEC. Class Action ClEARINGHOUSE, http://securities.stanford.edu (last visited Aug. 27, 2011).

40. I was able to obtain the entire case records for suits filed in federal court through the PACER system. The records for state court suits were more difficult to obtain because there is no central clearinghouse of state court dockets. I was generally able to obtain the dockets, and less often case filings, of state cases through the state court website, Westlaw, or Lexis. Given the unpredictability of obtaining these files, however, I coded less information for the state court cases.

41. I used the log of market capitalization.

42. I obtained the information regarding restatements from the company's public filings and Audit Analytics. I obtained the information regarding internal investigations from the company's own public statements. My coding on internal investigations is likely to be underinclusive because companies are not required to disclose internal investigations, and therefore, I learned about the investigation only if the company chose to disclose it. By the same token, many companies voluntarily disclose information regarding internal investigations to reassure investors who may be nervous about allegations of financial misstatements or other malfeasance.

43. This number reflects the number of consolidated cases in the study. There are several thousand constituent cases included in the dataset. 
A few caveats regarding the nature of the project and its methodology merit mention. First, the study is based on federal derivative suits filed in 2005 and 2006 , a time period that was chosen to allow the studied cases to reach final resolution. It is possible that the suits filed during this time period differ from suits filed in other time periods. Litigation reflects current events, and the suits in this study are no exception. Slightly more than $20 \%$ of the shareholder derivative suits in this study involved the alleged backdating of stock options.44 This wave of litigation, which dominated the business press for months, involved companies that dated stock options prior to the date that the companies actually granted the options.45 These suits were less likely to be accompanied by parallel securities class actions and were much more likely to end with the plaintiff corporation receiving a meaningful financial benefit. $4^{6}$ As discussed below in Part III, these suits provided more benefit to the plaintiff corporations and their shareholders than nearly any other type of shareholder derivative suit in recent times. As a result, this sample highlights the promise of shareholder litigation in a particular context while recognizing the problems associated with parallel corporate fraud litigation more generally.

Second, the incidence of parallel litigation may be even higher than the figures reflected in this study. As described above, I searched several databases and other sources of publicly available information to identify parallel litigation. This methodology, however, may not uncover all related lawsuits. The methods I used were most likely to uncover parallel securities class actions, SEC enforcement suits, and criminal investigations, especially those filed against publicly traded corporations because such suits are routinely disclosed through publicly available sources.47 These methods, however, may not have uncovered other parallel government investigations or private company suits. These search limitations mean that the prevalence of parallel litigation may be even higher than this study suggests.

\section{EMPIRICAL RESUltS}

With the above points in mind, this Part turns to the results of the study. The first Subpart provides a broad overview of the parallel world of corporate fraud litigation, describing the incidence of various types of parallel litigation and the allegations in these lawsuits. The next Subpart

44. Specifically, $22.6 \%$ of the cases ( 37 out of 164 ) involved allegations of backdating.

45. See Jesse M. Fried, Option Backdating and Its Implications, 65 WASH. \& L.E. L. REV. 853 . 860 (2008).

46. See infra note 121 and accompanying text.

47. For example, as noted above, the Stanford Securities Class Action Clearinghouse lists nearly all securities class actions filed in the United States. See supra note 39 and accompanying text. In addition, companies are required to disclose material litigation, and companies are likely to view SEC or criminal investigations as meeting this requirement even if other litigation does not. 
explores the interplay between these different types of parallel litigation, comparing the timing, the defendants named, and the ultimate outcomes in the suits. This Part focuses exclusively on the public company suits in the study,,$^{8}$ reserving analysis of the private company suits for Part III.

\section{A. THE PARALIEL WORLD OF CORPORATE FRAUD LITIGATION}

Corporate litigation today resembles a gold rush in which allegations of corporate fraud lead to a remarkable array of different lawsuits based on different legal theories. The analysis below begins with detailed data revealing the high incidence of parallel litigation in corporate law. I then describe the locus of these lawsuits, exploring a possible link between the rise of parallel litigation and the shift of corporate litigation away from Delaware. I finally explore data relating to the allegations in these parallel lawsuits, demonstrating that these lawsuits all turn on the same core allegation-fraud.

\section{Incidence of Parallel Litigation}

The incidence of parallel litigation in the study was staggering. Nearly $95 \%$ of the shareholder derivative suits filed on behalf of public companies in the study were accompanied by at least one parallel lawsuit or government investigation. More than $80 \%$ of the public company derivative suits were accompanied by two or more parallel lawsuits or government investigations. 49 Overall, the public companies examined faced a median of four different types of litigation..$^{\circ}$

The table below sets out the number of different types of lawsuits and government investigations faced by the public companies in the study..$^{1}$

48. Overall, $76.8 \%$ of the derivative suits in the study were filed on behalf of public companies. As discussed below in Part III.A, the private company suits look markedly different from their public company counterparts.

49. Specifically, $80.2 \%$ of the public company derivative suits in my sample were accompanied by two or more parallel types of litigation, such as a parallel securities class action, state derivative suit, ERISA action, or SEC investigation. I did not include in this figure shareholder derivative suits that were accompanied, for example, only by two securities class actions or by two ERISA class actions filed in different courts.

5o. This figure includes the shareholder derivative suits in the study, as well as the other litigation studied. See supra note 16 (describing the types of litigation included in this study).

$5^{1}$. This table illustrates the number of different types of litigation faced by the public companies in the study. For example, a company that faced three securities class actions, two state derivative suits, and one federal derivative suit was listed as facing three types of parallel litigation. This table includes the shareholder derivative suits in my study. 


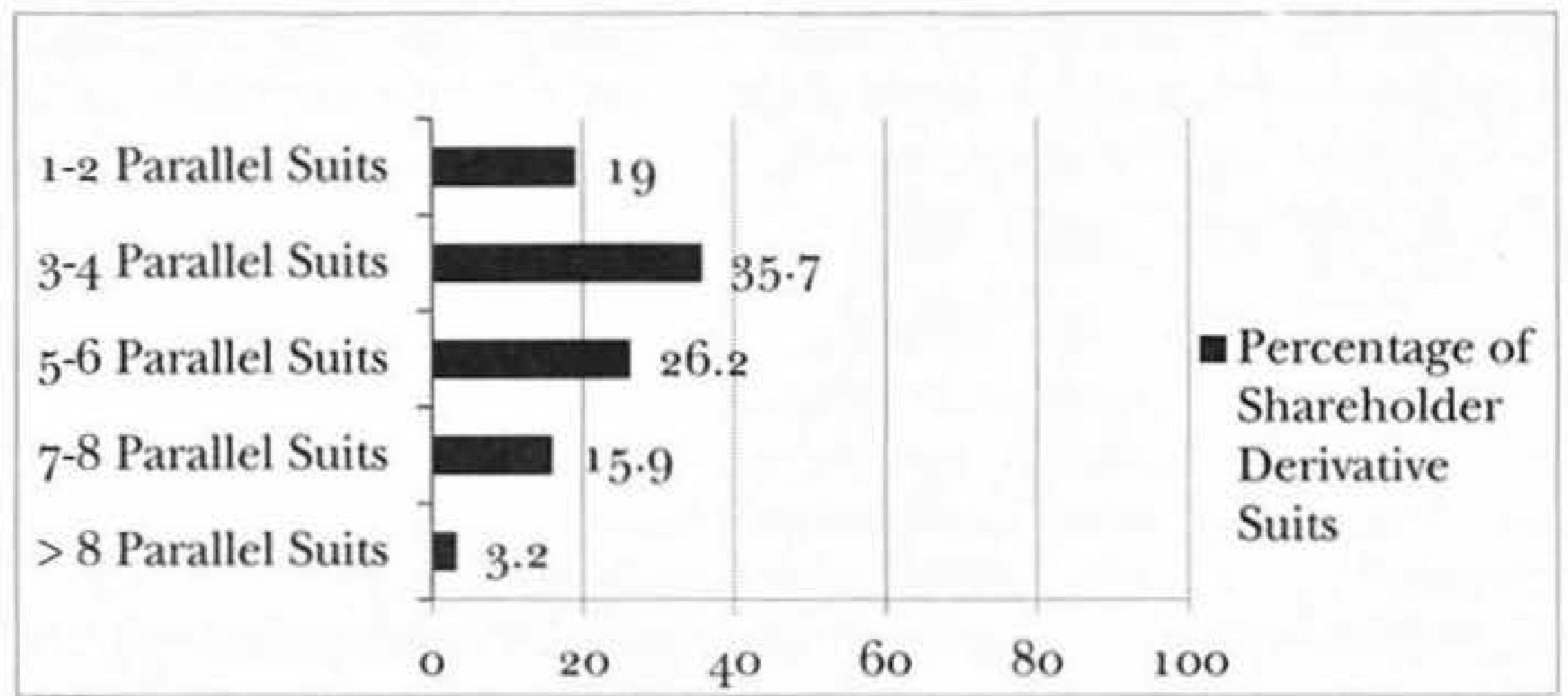

Table 1: Number of Parallel Lawsuits and Investigations Faced by Corporations Accused of Corporate Misconduct

The most common type of parallel lawsuits were securities class actions. Nearly three-quarters of the shareholder derivative suits in my sample $(74.9 \%)$ were accompanied by a parallel securities class action. A probit regression model identified several variables that increased the likelihood of a parallel securities class action..$^{2}$ A shareholder derivative suit was more likely to be accompanied by a parallel securities class action if (1) shareholders filed more than one shareholder derivative suit in the federal courts, (2) the suit involved a claim that the director defendants failed to provide proper oversight over the affairs of the corporation,53 (3) the suit did not include any nonderivative claims, or (4) the company restated its financial results. On the other hand, shareholder derivative suits that involved the alleged backdating of stock options were far less likely to be accompanied by a parallel securities class action.54 This result likely reflects the fact that many companies did not experience a steep stock price decline

52. I used the probit regression model throughout this section because the dependent variables were binary (either there was a parallel securities class action/SEC investigation/criminal investigation or there was not). All reported results are significant at the .05 level. The model incorporated key characteristics of the plaintiff corporation, including log of market capitalization, types of alleged misconduct, whether the corporation announced a restatement, and the number of shareholder derivative suits filed in the federal courts. A full list of variables is included in Table Ar of the Appendix.

53. This finding reflects the similarity between the allegations in the two types of suits. As discussed below in Part II.A.3, it is relatively easy for a shareholder to turn a federal securities claim that the corporations and its managers lied to the market into a claim that these managers breached their fiduciary duties by failing to prevent the alleged lies or by failing to prevent the underlying problems at issue.

54. In descriptive terms, only $57.1 \%$ of the stock option suits in the study were accompanied by a parallel securities class action, compared to more than $80 \%$ of the other shareholder derivative suits. 
following revelation of the backdating - a necessary predicate for a securities class action. 55

Other types of private suits were less common. Only $12.7 \%$ of the shareholder derivative suits in the study were accompanied by a parallel ERISA class action. The shareholder derivative suits in the study were most likely to be accompanied by a parallel ERISA suit if the derivative suit itself included federal securities claims,,$^{6}$ likely because such claims are extremely similar to the claims alleged in ERISA class actions. Another $18.3 \%$ of the suits in the study were accompanied by other private lawsuits, including consumer class actions, breach of contract actions, or antitrust suits. 57

The threat of liability in the study did not end with private litigation. The SEC launched an investigation in nearly $70 \%$ of the suits in the study. These investigations often ended with civil charges filed against the corporation or its managers. Overall, $30.2 \%$ of the shareholder derivative suits in the study were accompanied by SEC charges against the company, while $30.9 \%$ of the derivative suits were accompanied by SEC charges against an officer, director, or employee of the company. A probit model reveals that the SEC was more likely to launch a parallel investigation into the company's actions if the shareholder derivative suit involved alleged accounting errors or if the company restated its financial results..$^{8}$

Many of these defendants were subject to criminal investigations as well. Criminal authorities launched a parallel investigation against $43.7 \%$ of the public companies in the study. A probit model indicates that the DOJ or other criminal authorities are more likely to launch a parallel criminal investigation against these companies if the company allegedly backdated stock options. This finding reflects the fact that the U.S. Attorney for the Northern District of California sent subpoenas to a large number of

55. See, e.g., Daniel J. Morrissey, The Path of Comporate Law: Of Options Backdating, Derivative Suits, and the Business Judgment Rule, 86 OR. L. REV. 973, 993 (2007).

56. This finding reflects a probit regression model based on the independent variables included in the Appendix. This model also revealed that a parallel ERISA class action was less likely to accompany a federal derivative suit that alleged backdating of stock options. The list of variables included in this probit model is available in the Appendix. The model did not include allegations that the defendants failed to supervise the company's operations or made false and misleading statements to investors because the federal derivative suits in my study that were accompanied by parallel ERISA suits all included these allegations. All findings are significant at the .05 level.

57. This category included any private lawsuit that was not a securities class action, shareholder derivative suit, or ERISA class action.

58. This finding is based on a probit regression model incorporating the variables in the Appendix. I also performed a probit regression to determine when the SEC is likely to launch a parallel investigation against individual directors and officers, as opposed to the corporation. This model found that parallel SEC investigations against individuals are more likely if the shareholder derivative suit alleges insider trading and if the company restated its financial results. These findings are all significant at the .o5 level. 
companies following early revelations of backdating. ${ }^{59}$ These investigations turned into criminal charges against $4 \%$ of the public companies in the study. By contrast, individual defendants faced criminal charges in $14.3 \%$ of the shareholder derivative suits. Individuals are at a greater risk of criminal prosecution if there are allegations of insider trading or if the company restated its financial results. ${ }^{60}$

Finally, other government entities commenced investigations against $23.9 \%$ of the public companies in my sample. A wide array of federal entities initiated these investigations, including the Internal Revenue Service, the Department of Labor, the Food and Drug Administration, and congressional subcommittees.

Putting the data together, this study demonstrates that parallel litigation in the federal courts is the rule, not the exception. Returning to the diagram from Part I, a company named in a shareholder derivative suit has a significant chance of finding itself in a storm of litigation. ${ }^{61}$

59. See Stock-Option Grant Task Force Launched by U.S. Attorne, CIO MAGAZINE, July 14, 2006 , available at http://www.cio.com/article/22973/Stock_Option_Grant_Task_Force_Launched_ by_U.S._Attorney. Overall, $25.6 \%$ of the non-backdating suits were accompanied by a parallel criminal investigation, compared to $85.6 \%$ of the stock option suits.

6o. Again, this finding reflects a probit regression model based on the variables listed in Table Al of the Appendix. The findings are significant at the .05 level.

61. This study examines corporate fraud litigation through the specific lens of shareholder derivative suits. Accordingly, all of the companies in the study were named in a shareholder derivative suit. The other figures reflect the percentage of shareholder derivative suits accompanied by each type of parallel lawsuit. 


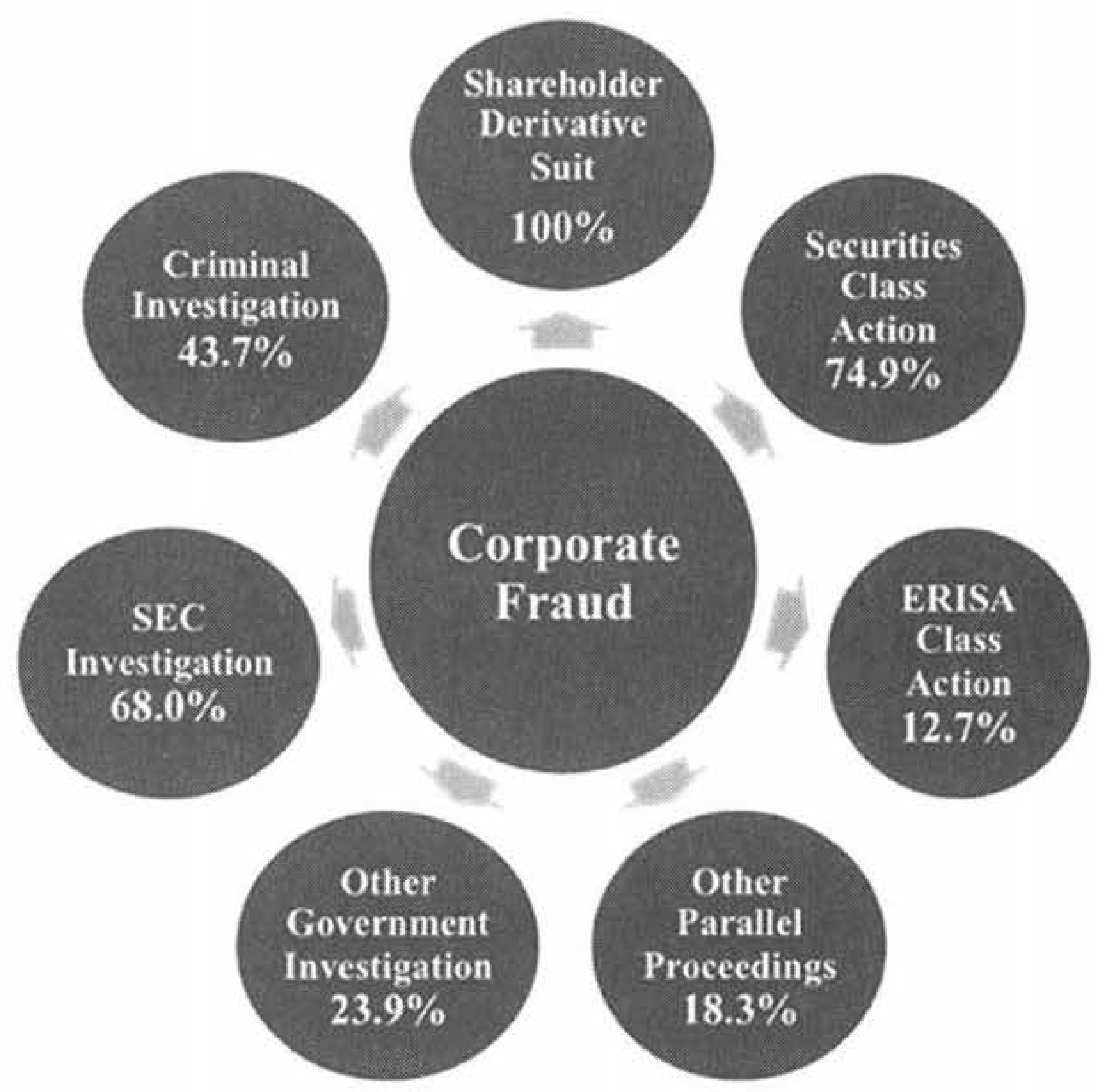

Figure 2. Percentage of Shareholder Derivative Suits Accompanied by Other Types of Parallel Litigation

Indeed, this diagram may not fully capture the gold rush of litigation that follows revelations of corporate fraud. In most cases, shareholders filed multiple lawsuits of a given type. For example, nearly two-thirds of the public company derivative suits involved more than one federal derivative suit, and more than one-quarter involved four or more federal derivative suits. More than half of the federal derivative suits in the study were accompanied by a parallel derivative suit filed in state court. Similarly, among the suits accompanied by a parallel securities class action, approximately two-thirds involved four or more class actions. These constituent cases were typically consolidated in a single proceeding, but they reflect the rush to the courtroom that typifies corporate fraud litigation.

To translate these data into current events, consider the ongoing litigation against Comverse Technology, Inc. ("Comverse"). For more than ten years, Comverse executives intentionally backdated the company's stock options, a scheme that allowed them to circumvent accounting rules and line their own pockets with millions of dollars. When this scheme came to light, Comverse and its executives were hit with an array of litigation, including securities class actions, shareholder derivative suits filed in state 
and federal court, SEC investigations against the company and three former senior executives, and criminal charges against several individuals. ${ }^{62}$ Comverse's founder and chief executive officer Kobi Alexander fled for the African country of Namibia, where he is currently fighting extradition..$_{3}$ His former colleagues have pled guilty to criminal charges, agreeing to disgorge millions of dollars in lost profits, and Comverse's former general counsel has been sentenced to more than a year in jail. ${ }^{64}$ In short, the alleged wrongdoers faced a sweeping set of lawsuits, all arising out of the same underlying allegations.

What does this mean for corporate fraud scholarship? First and foremost, it means that this scholarship must reflect the full panoply of litigation options. Viewing lawsuits in a vacuum leads to a distorted view of corporate fraud litigation. The discussion now turns to examining the geographical reach of this litigation in a quest to understand how the parallel world of litigation impacts other critical issues in corporate law.

\section{Locus of Parallel Litigation}

A remarkably high percentage of the parallel lawsuits in the study were filed in the same court, creating a locus of litigation within the federal courts. ${ }^{65}$ Table 2 indicates the percentage of each type of parallel suit that was filed in the same court as the federal derivative suit. ${ }^{66}$

62. Comverse Tech., Inc., Annual Report (Form 10-K) (Oct. 4, 2010), at 62-68, available at http://sec.gov/Archives/edgar/data/803014/o0o1 19312510223088/d tok.htm.

63. Mr. Alexander appears to be winning this fight, remaining out on bail since 2006. See Chamwe Kaira, U.S. Fugitive "Kobi" Alexander Wins Extradition Appeal, Namibian Reports, Bt.OOMBE.RG (Apr. 12, 2010), http://www.bloomberg.com/news/2010-04-12/u-s-fugitive-kobialexander-wins-extradition-appeal-namibian-reports.html; see also Ex-Comverse Chief Is Granted Bail in Namibia, DE.A1 BOOK (Oct. 3. 2006), http://dealbook.nytimes.com/2oo6/10/o3/ex-comversechief-is-granted-bail-in-namibia. Coincidentally, he has pledged to spend 100 million Namibian dollars to help the country, and the Namibian government has described him as "very passionate" about the country. Desiewaar Heita, Wanted U.S. Millionaire Starts Namibia Student Fund, REUTERS, Apr. 23, 2007 (internal quotation marks omitted), available at http://www. reuters.com/article/2007/04/23/us-namibia-millionaire-alexander-idUSL_2324973420070423.

64. Beth Bar, Former Comverse GC Sentenced to One Year. LAW.COM (May 11, 2007), http://www.law.com/jsp/cc/PubArticleCC.jsp?id=1 178787894514 .

65. The derivative plaintiffs relied on both federal question jurisdiction and diversity jurisdiction to get into federal court. Specifically, $38.1 \%$ of the cases relied on diversity jurisdiction, $36.5 \%$ relied on federal question jurisdiction (often in addition to supplemental jurisdiction for related state law claims), and $23.8 \%$ relied on both diversity and federal question jurisdiction. The federal statutory hooks for the federal question claims included sections 10 (b) 14, 16, and 20 of the Securities Exchange Act of 1934 and sections 304 and 7243 of Sarbanes-Oxley, among others.

66. The same pattern exists for the parallel shareholder derivative suits filed in state court. $54.8 \%$ of the federal derivative suits in the study were accompanied by a parallel state court derivative suit. In nearly all of the cases $(95.7 \%)$, at least one of the state court derivative suits was filed in the same state as the federal court derivative suit. Interestingly, however, in nearly $20 \%$ of the cases with a parallel state court derivative suit, shareholders filed state court suits in 


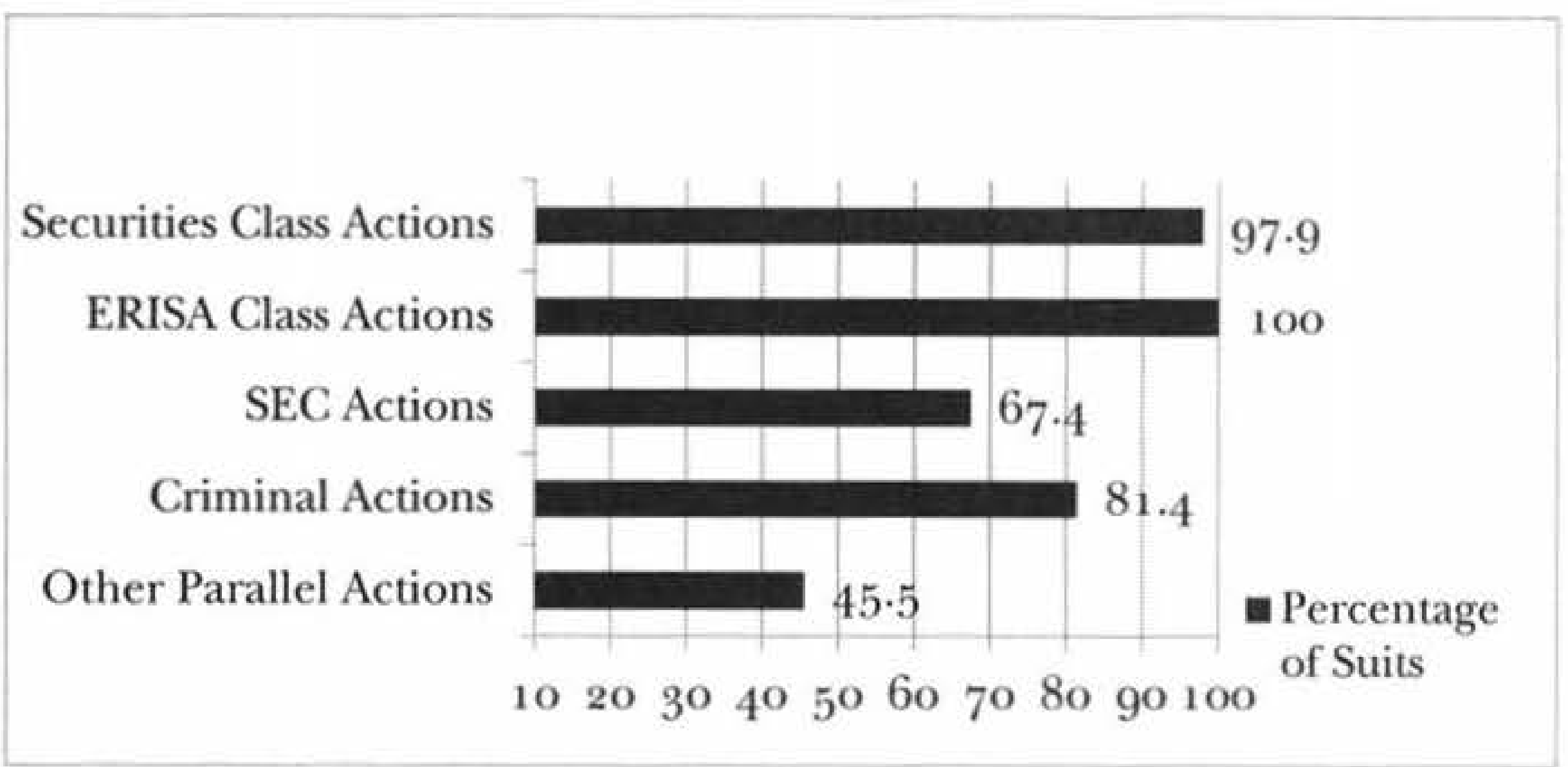

Table 2: Percentage of Parallel Lawsuits in the Same Court as the Shareholder Derivative Suit

These figures provide crucial insight into a question that has been vexing corporate law scholars: Why is corporate litigation moving away from Delaware? Conventional wisdom has long held that Delaware is the center of corporate law, and accordingly many scholars have focused their research on Delaware cases. ${ }^{67}$ Yet recent scholarship suggests that corporate litigation may be leaving Delaware in droves. According to a recent study by John Armour, Bernard Black, and Brian Cheffins, as recently as 1995 , over $80 \%$ of the cases filed against Delaware corporations were filed in the Delaware Court of Chancery. ${ }^{68}$ Over the last few years, however, this figure has dropped to less than $25 \% .69$

This shift of litigation has not gone unnoticed by the corporate bar. Theodore Mirvis, a well-known corporate defense lawyer, claims that plaintiffs' attorneys now use an "anywhere but Chancery" approach in selecting a venue for corporate litigation..$^{\circ}$ Although Delaware law applies to most of these disputes regardless of where they are filed,7' many plaintiffs' attorneys believe they have a better chance of prevailing outside of Delaware because non-Delaware judges are less likely to understand the complexity of

more than one state. These suits were typically filed in both the state in which the company was headquartered and the state in which the company was incorporated (typically Delaware).

67. See, e.g., Davis, supra note 5, at 389 ; Thompson \& Thomas, supra note 13 , at 1749 .

68. John Armour et al., Is Delaware Losing Its Cases? 12-13 (Eur. Corp. Gov't Inst., Law Working Paper No. 151/2010, 2011), available at htp://papers.ssm.com/sol3/papers.cfm? abstract id $=1578404 \&$ rec $=1 \&$ srcabs $=153^{1} 778$.

69. See id. at 13.

7o. See Ted Mirvis, Anywhere but Chancery: Ted Mirvis Sounds an Alarm and Suggests Some Solutions, M\&A J., May 2007 , at 17.

71. Choice of law rules dictate that the internal affairs of a corporation, including fiduciary duties, are determined by the state of incorporation. See In re Teleglobe Commc'ns. Corp., 493 F.3d 345, 385 n.37 (3d Cir. 2007). 
Delaware case law. $7^{2}$ Many Delaware doctrines have long and tortured histories, and Delaware law is replete with lengthy opinions that turn on complex corporate nuances.73 According to Mr. Mirvis, "trying to argue Delaware fiduciary duty cases outside of Delaware is like taking Gallatoire's secret recipes and giving them to a Jack-in-the-Box short-order cook." 74

As more and more cases leave Delaware, courts have started to suggest steps to reverse the trend. In a recent decision that was sharply critical of the shareholder plaintiffs' bar, Vice Chancellor Laster of the Delaware Court of Chancery stated that "if boards of directors and stockholders believe that a particular forum would provide an efficient and value-promoting locus for dispute resolution, then corporations are free to respond with charter provisions selecting an exclusive forum for intra-entity disputes."75 Although he did not expressly suggest Delaware as the ideal forum of choice, one can surmise that he favors his home courts. Wachtell, Lipton, Rosen \& Katz, a leading corporate defense firm, has taken up the charge, recommending to its corporate clients that they adopt a charter amendment requiring that the Delaware Court of Chancery be the "sole and exclusive forum" for any breach of fiduciary duty suit filed against the company or its officers, directors, or shareholders. ${ }^{76}$ These solutions seek to halt perceived forum shopping by plaintiffs' attorneys allegedly anxious to avoid the business-savy and watchful eye of the Delaware judiciary.

Yet perhaps shareholder derivative suits are moving to the federal courts for another reason-the rise of parallel litigation. As the data above indicate, a significant percentage of shareholder derivative suits are accompanied by at least one parallel lawsuit, most commonly a securities class action filed in federal court. There is nothing surprising about a derivative plaintiff filing a lawsuit in the same court as multiple other related suits. 77 Indeed, it would be more surprising if the derivative plaintiff filed suit in Delaware when nearly all of the other related litigation was in the federal courts..$^{8}$

Moreover, it often makes sense for these lawsuits to be consolidated in the federal courts. Consolidation, typically before a single judge, allows significant efficiencies in litigation resources. Only one judge must learn the complex facts underlying the suits, and the parties are often able to

72. See Mirvis, supra note 70 , at 17 .

73. See id.

74. See id.

75. In re Revlon, Inc. S'holders Litig., 990 A.2d 940, 960 (Del. Ch. 2010).

76. See Memorandum from Wachtell, Lipton, Rosen \& Katz to Boards of Directors (June 2010) (on file with author).

77. This explanation relates only to shareholder derivative suits. It does not relate to other types of shareholder lawsuits, specifically including acquisition class actions.

78. This point is bolstered by the fact that shareholder derivative suits are typically filed after other parallel litigation, as discussed below. See infra note 98 and accompanying text. 
coordinate discovery and other pretrial proceedings. It would be impossible to obtain such economies of scale in the Delaware Court of Chancery or any other state court because most corporate fraud litigation (other than shareholder derivative suits) arises under federal law and is subject to exclusive jurisdiction in the federal courts. 79 Accordingly, the federal courts are often the only venue in which all related litigation can be heard.

In addition, federal judges are accustomed to complex cases and complicated legal doctrine. Federal judges in the Southern District of New York or the Northern District of California may not be steeped in the details of Delaware corporate law, ${ }^{80}$ but few would doubt their ability to get up to speed on these doctrines quickly when overseeing a state fiduciary duty case. Indeed, federal judges sitting in diversity must often learn complex areas of state law.

Finally, the attorneys in the study were not filing lawsuits in jurisdictions with little connection to the dispute. Nearly $95 \%$ of the federal derivative suits in this study were filed in federal courts located in the state in which the plaintiff corporation was headquartered. These figures suggest that any forum shopping is fairly limited. ${ }^{8 t}$

In sum, corporate litigation may be leaving Delaware, but that is not necessarily a bad thing. As we will see, the rise of parallel litigation also challenges more fundamental assumptions regarding the types of allegations in corporate litigation.

\section{Allegations in Parallel Litigation}

Scholars have long presumed that different types of corporate lawsuits target different types of misconduct. According to this accepted wisdom, shareholder derivative suits target traditional forms of corporate malfeasance such as self-dealing or usurpation of corporate opportunities, ${ }^{82}$

79. See 15 U.S.C. $\$ 78$ aa (2006) (amended 2010).

8o. As 1 have discussed elsewhere, nearly half of shareholder derivative suits filed in federal court are filed in district courts in the Second Circuit or the Ninth Circuit. See Erickson, supra note 12 , at 1764 .

81. This analysis is not meant to suggest that derivative plaintiffs do not engage in forum shopping. Many likely do, especially when it comes to shareholder derivative suits filed in state courts, which are outside the scope of this study. State court suits do not benefit from the same economies of scale that are possible on the federal side, and state court judges may not have the experience overseeing large-scale litigation. Yet the shift of litigation into the federal courts suggests that other factors are driving this phenomenon as well.

82. See, e.g., Davis, supra note 5, at $4{ }^{14}$ ("Today's derivative suit therefore may function mostly as the repository for self-dealing and other duty of loyalty claims that neither arise in an acquisition context nor involve substantial stock market losses."); Reinier Kraakman et al., When Are Shareholder Suits in Shareholder Interests?, 82 GEO. L.J. 1733, 1733 (1994). 
while securities class actions and SEC enforcement suits target corporate fraud and other misstatements to the market. ${ }^{8}$

The parallel lawsuits in this study, however, challenge the notion that corporate litigation divides in this manner. Nearly all of the shareholder derivative suits in the study turned on allegations of corporate fraud. Specifically, more than $90 \%$ included allegations of false or misleading statements, the same allegations that are the cornerstone of fraud claims. ${ }^{8}$ Shareholder derivative suits even target the same kind of fraud as securities class actions. More than $80 \%$ of the shareholder derivative suits in the study included allegations of accounting misstatements-the "predominant claim" in modern securities class actions. ${ }^{85}$ Approximately $60 \%$ of the public company derivative suits included allegations of insider trading. ${ }^{86}$ Again, these allegations are commonly seen in securities class actions. ${ }^{87}$ As this comparison demonstrates, shareholder derivative suits and securities class actions target fraud from different legal angles-securities class actions target fraud directly, while shareholder derivative suits tend to target the underlying conduct that led to the alleged fraud-but the core factual allegations are the same.

The storm of litigation that hit American International Group, Inc. ("AIG") illustrates this phenomenon. At the height of the financial boom, AIG was one of the largest holders of subprime mortgages. ${ }^{88}$ This investment strategy proved to be a ticking time bomb when the residential housing market collapsed in 2008. AIG was forced to seek hundreds of millions of dollars in federal funds to stay afloat, a bailout that Federal Reserve Chairman Ben Bernanke has called "the event that [has] made him the

83. Sec 17 C.F.R. $\$ 240.10 b-5$ (2010) (prohibiting false or misleading statements in connection with the purchase or sale of securities).

84. These figures reflect shareholder derivative suits in the federal courts. As discussed in greater detail below, it is possible that derivative suits filed in state court allege other kinds of corporate malfeasance.

85. See Coffee, supra note 4 , at 1544 .

86. This percentage is based on the 101 classic public company suits or the suits that did not include allegations of backdated stock options. I did not include the stock option suits in this calculation because the derivative plaintiffs in these suits often included allegations of insider trading in their complaints but did not specify whether these allegations were separate from the backdating claims.

87. See CORNE.rStONE RESEARCH, SECURITIES Cilass ACtION GASE. FilingS: 2006: A YeAr IN REVIEW 20 (2007), available at http://securities.stanford.edu/clearinghouse_research/2006_ YIR/20070102-01.pdf (providing data on insider trading allegations in securities class actions filed during the period covered by this study).

88. See Serena Ng, Hedge Funds May Get AIG Cash, WAL. ST. J., Mar. 18, 2009, at A1, A2 ("AIG was by far the single largest ultimate taker of risk in the [subprime mortgage] CDO space." (alteration in original) (quoting a senior investment banker) (internal quotation marks omitted)). 
angriest since the [financial] crisis began." ${ }^{8}$ Following the government's rescue, AIG was hit with a barrage of litigation, including securities class actions in the United States and Canada, ERISA class actions, shareholder derivative suits in five different state and federal courts, and an array of government investigations. $9^{\circ}$

These lawsuits all turned on one common question: Did AIG managers break the law by authorizing and then allegedly hiding its risky bets on subprime mortgages? In the securities class action complaint, the plaintiff alleged that the defendants misled the market regarding the riskiness of AIG's investments, including "outright falsehoods" concerning AIG's internal controls. ${ }^{91}$ In the shareholder derivative suits, the plaintiffs attacked the investments from a slightly different angle, arguing that AIG's top managers consciously disregarded the risks associated with these investments, "improperly conceal[ing] the true extent of the exposure" to the risk..$^{2}$ In the ERISA class action, the plaintiffs alleged that the company and its executives continued to offer AIG stock as an investment option for employees despite mounting risks to the company's financial health. ${ }^{93}$ The FBI even launched a criminal investigation to determine whether AIG's reckless investments had caused the company to knowingly misstate its accounting results. 94

What does this phenomenon say about the deterrent value of shareholder derivative suits? As discussed above, scholars have long justified these suits on the ground that they are necessary to deter corporate managers' misconduct.95 The modern reality of corporate fraud litigation complicates this traditional rationale. Given that nearly three-quarters of shareholder derivative suits are accompanied by a parallel securities class action, do derivative suits offer deterrent value that these securities class actions do not? Similarly, will corporate managers, who already face the

89. Rich Miller \& Julianna Goldman, Bernanke Outshines Obama Team with Defense of Government Efforts, BLOOMBERG (Mar. 17, 2009), http://www.bloomberg.com/apps/news? pid= newsarchive \&sid=aGpBlzh8xoXY.

9o. See Am. Int'l Grp., Inc., Annual Report (Form 10-K), at 293-97 (Feb, 26, 2010).

91. Consolidated Class Action Complaint I 18, In re Am. Int'l Grp., Inc. 2008 Sec. Litig., No. 08-CV-4772-LTS (S.D.N.Y. May 19, 2009), 2009 WL 1507054 . These lawsuits were filed outside the time period covered by this study, but they illustrate an even more recent example of parallel corporate fraud allegations.

92. Verified Shareholder Derivative Complaint for Breach of Fiduciary Duty, Waste of Corporate Assets, Unjust Enrichment and Violations of the Securities Exchange Act of 1934 at 1, In re Am. Int'l Grp., Inc. Derivative Litig., 700 F. Supp. 2d 419 (S.D.N.Y. 2010) (No. o7 Civ. 10464), affd, $4^{1} 5$ F. App'x 285 (2d Cir. 2011 ), 2007 WL 4840032.

93. See Consolidated Amended Complaint I 4, In re Am. Int'I Grp., Inc. ERISA Litig. II, No. 08 Civ. 5722 (LTS) (KNF) (S.D.N.Y. June 26, 2009), 2009 WL 4061516.

94. See Robert Schmidt, FBI Subprime Probe Adds Fannie, Freddie, AIG, Lehman, BLOOMBERG (Sept. 24, 2008), http://www.bloomberg.com/apps/news?pid=newsarchive\&sid= a_oZZHsX.QIM.

95. See supra notes $4-5$. 
possibility of charges from the DOJ and the SEC, decide not to engage in corporate malfeasance because of the threat of a shareholder derivative suit? The focus now turns to answering these questions in an effort to determine the role of shareholder derivative suits within the larger world of corporate fraud litigation.

\section{B. SHAREHOLDER DERIVATIVE SUITS AS PARALIEL LITIGATION}

As the previous section demonstrates, corporate fraud allegations typically trigger a wave of parallel lawsuits. This section explores this interplay between these lawsuits, focusing specifically on the role of shareholder derivative suits within the larger landscape of corporate fraud litigation. First, I examine the timing of the suits, exploring the possibility that certain lawsuits serve a whistle-blower function by alerting other potential litigants of corporate misconduct. Second, I examine the defendants sued in the various types of suits, analyzing whether different lawsuits target different defendants. Finally, I compare the outcomes of the various suits, examining whether these different outcomes are likely to lead to different levels of deterrence.

\section{Comparing Filing Dates}

Corporate fraud litigation has long been characterized by a race to the courthouse, with numerous lawsuits filed within weeks or even days of the first hint of corporate malfeasance.$^{6}$ Litigation can serve a whistle-blowing function by discovering this malfeasance, and thus the first attorneys through the courthouse doors may play a role in uncovering the alleged fraud or other malfeasance at issue in the later suits.

Of course, the first filed lawsuit is not always the most meritorious. Plaintiffs' attorneys may mistake bad luck or poor market conditions for fraud, filing lawsuits before gathering concrete evidence of malfeasance. In other instances, the company may blow the whistle on its own misconduct by announcing a restatement or internal investigation. 97 Still, there are many instances in which enterprising attorneys take available facts and piece together a theory of legal liability. Comparing filing dates is therefore an important first step in evaluating the relative merits of these parallel lawsuits.

The results of this comparison are striking. Among the cases examined in this study, the shareholder derivative suits were consistently filed after both the securities class actions and SEC enforcement actions. $9^{9}$ The shareholder

96. See, e.g., Elliott J. Weiss, The Lead Plaintiff Provisions of the PSLRA After a Decade, or "Look What's Happened to My Baby," 61 VAND. L. REV. 543,564 (2008) (stating that "the race to be the first to file-and to post a notice of filing on the internet-continues").

97. The broad disclosure requirements of the federal securities laws often require companies to disclose the initial facts relevant to the alleged wrongdoing.

98. The sixteen ERISA suits in this study did not follow this broader pattern. They were filed a median of thirty-six days after the first filed federal derivative suit, but there were too few 
derivative suits were filed after a parallel securities class action in $82.1 \%$ of the cases, with federal derivative suits filed a median of twenty-three days after parallel securities class actions. Similarly, the shareholder derivative suits in the study were filed after the commencement of a parallel SEC investigation in $79 \%$ of the cases, with the derivative suits filed a median of 21.5 days after the commencement of an SEC investigation. T-tests indicate that the filing dates of shareholder derivative suits filed in federal courts are statistically different at the $95 \%$ confidence level from the filing dates of securities class actions and SEC enforcement suits.

The data also suggest that most corporate fraud litigation is filed within a fairly short window of time. This is especially true in comparing the filing dates of federal derivative suits and securities class actions. In this study, $65.3 \%$ of the parallel securities class actions were filed within sixty days of the federal derivative suit. A smaller, but still notable, percentage of the other lawsuits were filed within this relatively short window of time-6o. $8 \%$ of the criminal investigations, $48.7 \%$ of the SEC investigations, and $56.7 \%$ of the state court derivative suits. Figure 3 below illustrates the typical litigation timeline in the wake of revelations of corporate malfeasance.99

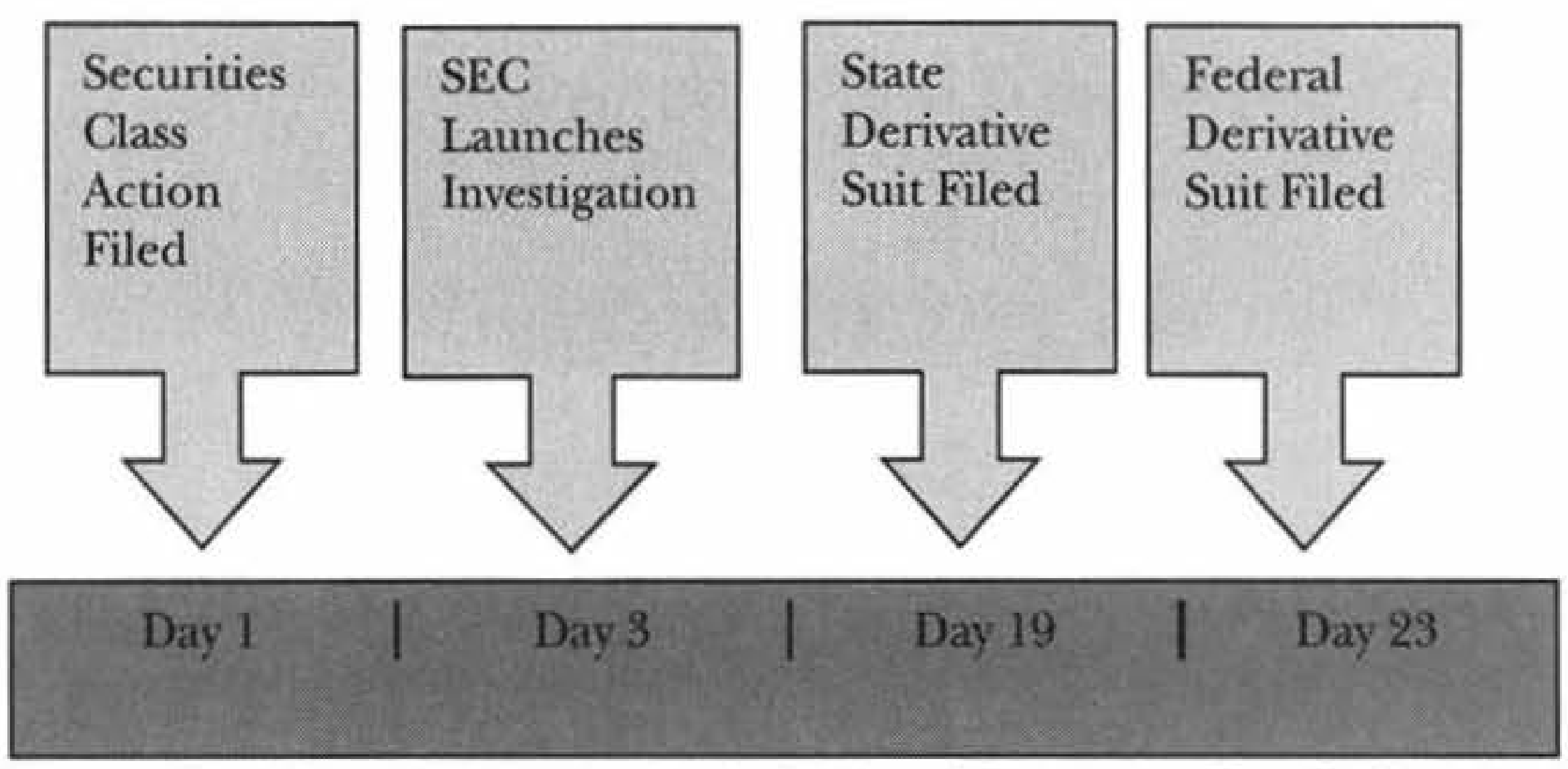

Figure 3. Timeline of Litigation in the Wake of Corporate Fraud Allegations

The data suggest that many shareholder derivative suits simply piggyback on securities class actions and other types of corporate fraud lawsuits. The shareholder derivative suits in the study rarely acted as whistleblowers, alerting the government and other private plaintiffs of the alleged fraud. Instead, these suits typically followed quickly on the heels of other

parallel ERISA suits in my sample to draw a meaningful conclusion about the timing of such suits.

99. I have included the state court derivative suits in this timeline. These suits were filed a median of four days before the federal suits. The start dates of the state suits are statistically different from the start dates of the federal suits at the $90 \%$ confidence level. 
lawsuits, especially securities class actions and SEC enforcement suits. Indeed, this timing presents the possibility that attorneys who file shareholder derivative suits may watch for promising lawsuits and then use the allegations in these suits to craft a parallel shareholder derivative suit.

Yet, even if lawsuits do not blow the whistle on corporate fraud, they may still deter corporate fraud by targeting different defendants or ending with different sanctions, two possibilities that are discussed below.

\section{Comparing Defendants}

Do different types of corporate fraud lawsuits target different types of defendants? Corporate law scholarship has long assumed that securities class actions and government enforcement actions target officers, while shareholder derivative suits target directors. ${ }^{100}$ This assumption, however, is only partially supported by the data. As the data reveal, many corporate officers are targeted in a wide array of lawsuits, not just securities class actions and SEC actions. Consistent with the conventional wisdom, however, shareholder derivative suits are often the only suits to target corporate directors.

Senior corporate officers are squarely in the litigation bull's-eye. Table 3 illustrates that chief executive officers ("CEOs") and chief financial officers ("CFOs") are typically named in numerous parallel lawsuits.

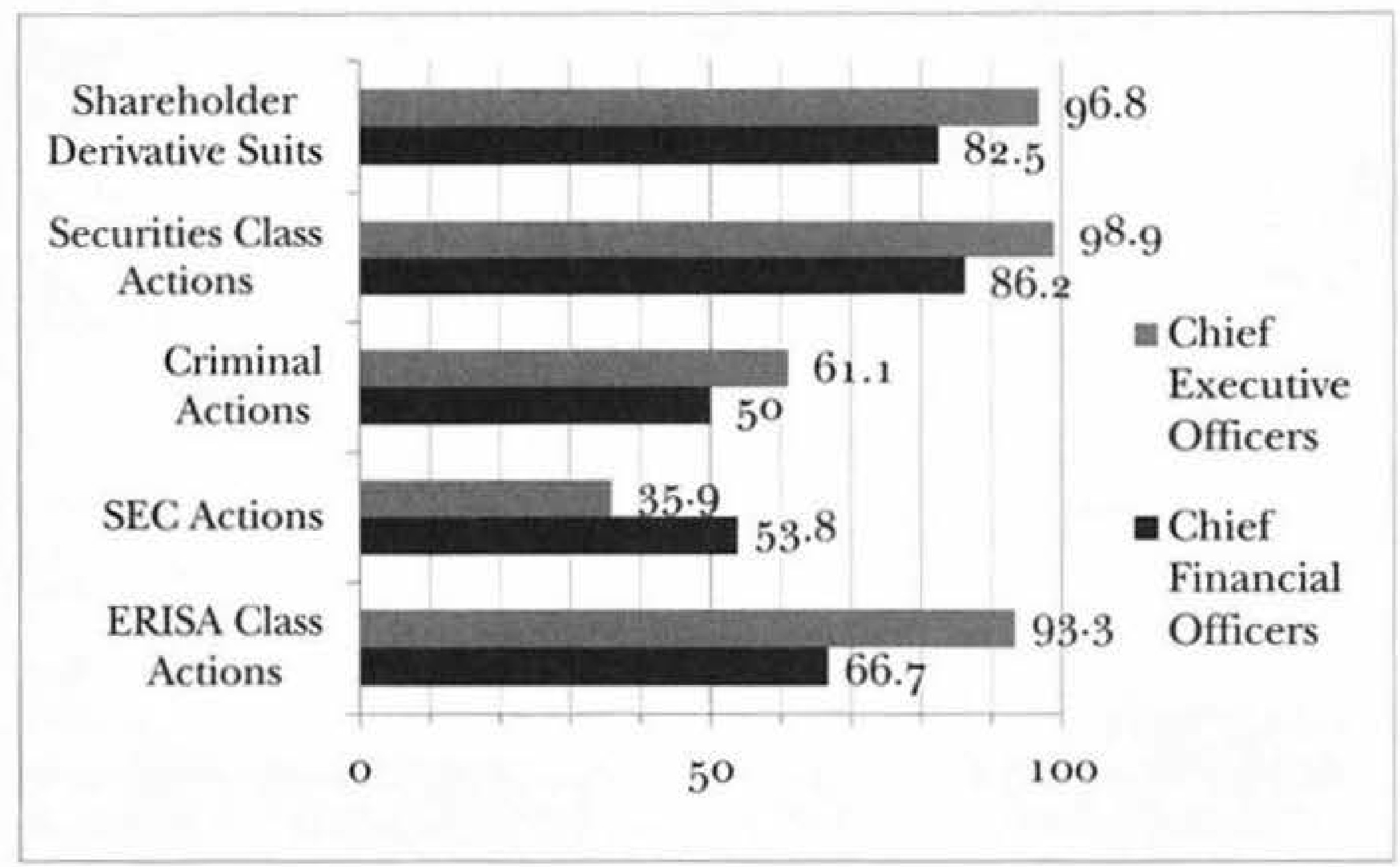

Table 3. Percentage of Corporate Fraud Lawsuits Targeting CEOs and CFOs

100. Robert B. Thompson \& Hillary A. Sale, Securities Fraud as Corporate Governance: Reflections upon Federalism, 56 VAND. L. REV. 859. 895 (2003) ("State law fiduciary duty complaints are brought against directors, but federal claims are made against officers."). 
As this table demonstrates, CEOs or CFOs at companies accused of fraud or other misconduct have multiple targets on their backs.

Moving down the organizational chart, however, other officers, such as corporate vice presidents or department heads, were targeted far less often. The shareholder derivative suits in the study typically named two officer defendants other than the CEO and CFO. Most commonly, the securities class action named one of these lower officers and did not name any additional officer defendants. The government used an even more focused approach. The SEC filed charges against only $25 \%$ of the officer defendants named in the shareholder derivative suits, and the DOJ or other criminal agencies named only $21.4 \%$ of the officer defendants from the shareholder derivative suit. ${ }^{\circ}$

At first glance, these data suggest that shareholder derivative suits may play a role in deterring lower-level officers who are not targeted in other litigation. Interestingly, however, the federal government often pursued charges against officers not named in the shareholder derivative suit. Nearly half of the SEC enforcement suits against individuals named an officer who was not named in the federal derivative suit, as did nearly $40 \%$ of the criminal suits against individuals. These figures suggest that derivative plaintiffs sweep broadly but may still miss the key wrongdoers in the case..$^{102}$

The data regarding corporate directors present a very different story. The shareholder derivative suits in the study were often the only suits to target outside directors, or directors who did not also serve in an executive capacity at the corporation. Nearly all of the shareholder derivative suits named at least one outside director as a defendant. These suits targeted a median of seven outside directors, a number that reflects the fact that derivative plaintiffs typically target the entire board. As Table 4 demonstrates, outside directors were named far less often in the other types of corporate fraud lawsuits in the study.

101. These data focus solely on government enforcement lawsuits filed against individual defendants. Data regarding the percentage of SEC investigations targeting corporate officers or directors are not available because individuals, unlike public companies, are not required to disclose the fact that they are the subject of a government investigation.

102. The government may also have strategic reasons for going after lower-level officers. The government, for example, may think that these officers will provide information that the government can use in exchange for more lenient treatment. 


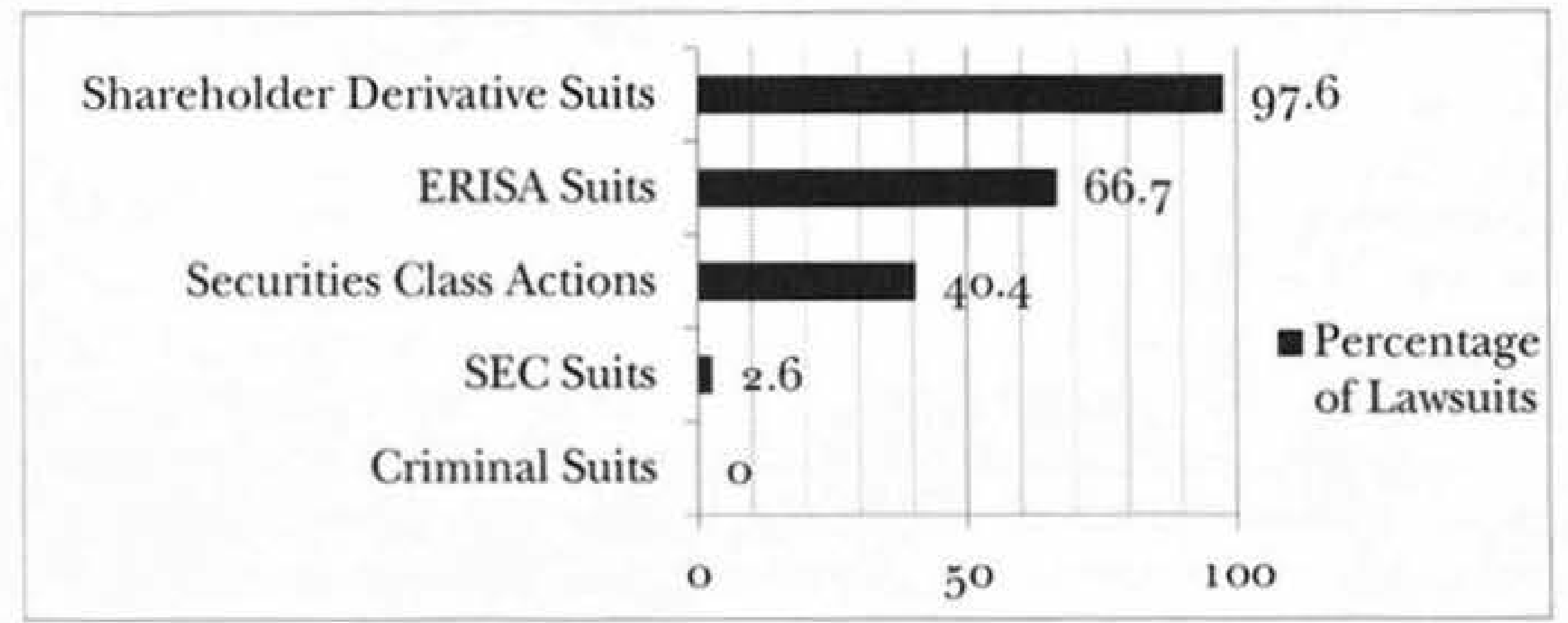

Table 4. Percentage of Corporate Fraud Lawsuits Targeting at Least One Outside Director

None of the criminal investigations in the study ended with charges against an outside director, and only one of the SEC investigations ended with charges against an outside director. ${ }^{103} \mathrm{~A}$ larger percentage of securities class actions and ERISA lawsuits included claims against an outside director, but an outside director still has a far greater chance of being targeted in a shareholder derivative suit.

These findings suggest that the greatest potential for shareholder derivative suits may lie in deterring outside directors. Ironically, as discussed in Part III below, this value is undercut by the substantive law in most derivative suits, reflecting a deep ambivalence in corporate law regarding the liability of outside directors. ${ }^{104}$ By the same token, shareholder derivative suits may have less value in deterring corporate officers. Corporate CEOs and CFOs typically face several lawsuits, including securities class actions, SEC enforcement suits, and even criminal actions. Corporate officers further down the chain of command are named less often in every type of corporate fraud lawsuit, and there is some evidence that shareholder derivative suits may miss potential defendants.

Yet deterrence can come from many angles. Even if corporate fraud lawsuits target many of the same defendants, they can still have independent value if they lead to different sanctions. The analysis now turns to this final possibility.

\section{Comparing Judgments}

The final, and perhaps most important, consideration in determining the deterrent value of corporate fraud lawsuits is to examine how these

103. See Press Release, SEC, Outside Directors of Mercury Interactive Settle SEC Charges of Stock Option Backdating (Sept. 17, 2008), available at http://www.sec.gov/news/press/2008/ 2008-208.htm (announcing a settlement with three outside directors of Mercury Interactive based on the directors' alleged recklessness in approving backdated stock options).

104. See infra notes $165-74$. 
lawsuits typically end. Under traditional theories of deterrence, corporate managers who are contemplating committing corporate fraud or other malfeasance will weigh the expected benefits of the act against the expected costs. $^{105}$ These expected costs include the penalties and sanctions that the managers will face if they are caught. ${ }^{106}$ These penalties accordingly play a key role in deterring corporate fraud.

Shareholder derivative suits have the potential to shine at this stage of the analysis. Unlike other types of corporate fraud litigation, shareholder derivative suits almost exclusively target individuals. In contrast, the other types of lawsuits in the study often targeted both individual and corporate defendants, with the individuals rarely paying any money in the final settlement.

The securities class actions in the study illustrate this point. More than $60 \%$ of the securities class actions settled, ${ }^{107}$ and these settlements were sizable, with a median value of $\$ 18$ million. Yet the settlement agreements typically stated that the company would pay the full settlement amount. ${ }^{108}$ The company was often then reimbursed for some or all of the settlement amount by the directors' and officers' ("D\&O") insurance policy. In either instance, the individual defendants rarely had to contribute a penny to settle the claims. ${ }^{\circ 9}$ Moreover, given that corporations pay the premiums for D\&O insurance, the individuals also did not have to worry about increased premiums as a result of the settlements. In other words, although individual officers and directors are often named in securities class actions, corporations bear the brunt of the financial costs. As scholars have recognized, the ability of corporate managers to shift the cost of their

105. See Gary S. Becker, Crime and Punishment: An Economic Approach, in EsSAYS IN THE. ECONOMICS OF Crime AND PUNISHMENT 1 (Gary S. Becker \& William M. Landes eds., 1974). Many scholars have extended this theory into the corporate realm. See, e.g., Miriam H. Baer, Linkage and the Deterrence of Corporate Fraud, 94 VA. L. REv. 1295, 1302-05 (2008) (analyzing theories of deterrence in corporate law); Coffee, supra note 4 , at ${ }_{155} 6-66$ (analyzing Becker's theory in the corporate context).

106. This formulation is a simplistic account of Becker's theory-corporate wrongdoers likely do not engage in a rigorous cost-benefit analysis, and other factors such as the wrongdoer's evaluation of the risk may well impact the analysis. These refinements are addressed further in Part III.

107. Specifically, $61.7 \%$ of the securities class actions settled, $26.6 \%$ were involuntarily dismissed, $2.1 \%$ were voluntarily dismissed, and $9.6 \%$ were still pending. None of the securities class actions in this study went to trial.

108. In a handful of the cases, a portion of this amount was paid by the outside auditor or another third-party defendant.

109. There were a few exceptions, often in the highest-profile cases, where the individual defendants did contribute to the settlement fund. In the securities class actions arising out of the backdating scandal at Comverse Technology discussed above, for example, former CEO Kobi Alexander contributed \$6o million to the $\$ 225$ million settlement fund. See Stipulation of Settlement I 2.3, In re Comverse Tech., Inc. Sec. Litig., 543 F. Supp. 2 d 134 (E.D.N.Y. Feb. 20, 2008), 2009 WL $5^{1} 4^{6869}$. 
misconduct to their corporate employers significantly undercuts the deterrent effect of securities class actions. ${ }^{110}$

Government enforcement actions are more promising from the standpoint of individual deterrence. The government often targets individuals, "' and these individuals are far more likely than their corporate counterparts to pay financial penalties or face other meaningful sanctions. For example, approximately $75 \%$ of the SEC suits against individuals in the study ended with one or more individuals paying money out of their own pockets to settle the claims against them. "iz Slightly more than $50 \%$ of these suits ended with an individual defendant agreeing to a ban on serving as a director or officer of a public company for a specified period of time. Nearly $80 \%$ of the criminal suits filed against individuals ended with a guilty plea or jury verdict against one or more defendants, and these defendants often had to pay steep fines or serve jail time.

These stiff sanctions, however, were only imposed on a few individuals at the target corporations. As detailed above, less than one-third of the shareholder derivative suits in this study were accompanied by SEC lawsuits against individuals. ${ }^{13}$ Moreover, the SEC typically targets a narrow group of individuals, and this group typically does not include any corporate directors or officers who were not centrally involved in the alleged fraud.

These findings present a window of opportunity for shareholder derivative suits. These suits have the potential to have a broader deterrent impact than other types of corporate fraud lawsuits if they end with sanctions against a broader group of defendants. ${ }^{\prime \prime} 4$ This is especially true given that corporations are the plaintiffs, not codefendants, in these suits, and therefore, corporations cannot pay settlement amounts on the individuals' behalf.

Yet the shareholder derivative suits in the study rarely lived up to this potential. Nearly $60 \%$ of these suits were dismissed, an outcome that offers

110. Coffee, supra note 4 , at 1553 ("[1]f the insiders who are most culpable can apparently escape personal liability in securities class actions, then the deterrent rationale for that action seems largely undercut.").

111. Specifically, thirty-nine of the seventy-seven SEC enforcement suits in the sample $(50.6 \%)$ were filed against individuals, and eighteen of the twenty-three criminal suits in the study $(78.3 \%)$ were filed against individuals.

112. These settlement agreements typically stated that the individual defendants would not seek to be reimbursed by their employer or their insurance company. See, eg.. Amended Final Judgment at $7-8$, SEC v. Treacy, No. 08-CV-4052 (S.D.N.Y. May 28, 2010) (stating that the defendant agrees that he will not seek reimbursement or indemnification for any civil penalties paid to the SEC).

113. See supra text accompanying note 58 .

114. See, e.g., James D. Cox, The Social Meaning of Shareholder Suits, 65 BROOK. L. REV. 3. $4^{\circ}$ (1999) ("Deterrence is poorly served and the suit is robbed of its public character when its defendants are not called upon to make a significant contribution to the settlement."). 
little in the way of deterrence. ${ }^{15}$ The remaining $40 \%$ of the suits ended in a settlement, a far lower percentage than in corporate litigation more generally. ${ }^{116}$ Yet even these settlements packed little punch when it came to deterring corporate fraud. As I have discussed elsewhere, remarkably few of the settlements involved financial consideration, and even fewer of the settlements involved financial consideration that actually benefited the plaintiff corporation. ${ }^{17}$

Setting aside the stock option suits, which are discussed below, only $3.3 \%$ of shareholder derivative suits in the study involved a settlement in which the plaintiff corporation received money or another meaningful financial benefit. ${ }^{118}$ The remaining settlements in these suits were corporate governance settlements or settlements in which the plaintiff corporation agreed to relinquish claims against its officers and directors in exchange for reforming its own corporate governance practices. Although these settlements had the potential to benefit corporations, the majority included only cosmetic reforms that did little to remedy the alleged governance problems. ${ }^{19}$

Moreover, shareholder derivative suits are about deterrence, not corporate governance reform, ${ }^{120}$ and on this score, the settlements also fall short. A corporate officer or director who is contemplating engaging in fraud or other misconduct is unlikely to be deterred by the threat of a corporate governance settlement. Even if the settlements included meaningful corporate governance reforms, the settlements targeted plaintiff corporations, not the individual wrongdoers. Officers and directors may be required to play a role in these reforms, but this role is typically minimal, such as attending additional training sessions or meeting in executive sessions at board meetings. Moreover, individual defendants who have left the company are not impacted by these settlements at all. Viewed through the lens of deterrence, these settlements are therefore even less promising than the settlements in other parallel lawsuits.

115. As I discuss below in Part III, corporate managers may be deterred simply by the threat of being named in a lawsuit, regardless of its ultimate outcome.

116. Securities class actions, for example, have roughly the opposite ratio of settled and dismissed cases. Studies have found that nearly $60 \%$ of securities class actions settle, while $40 \%$ are dismissed by the court. See CORnerstone. Rese.ArCh, SECurities Class Action Filings: 2010 YEAR IN REVIEW 14, available at http://securities.stanford.edu/clearinghouse_research/ 2010_YIR/Cornerstone_Research_Filings_2010_YIR.pdf.

117. For a detailed analysis of these settlements, see Erickson, supra note 12, at 1799-1805.

118. See id. at $179^{8-1804}$. Specifically, three settlements out of the eighty-nine classic public company suits filed in federal court involved a settlement with a meaningful financial benefit, such as money or financial protection in another lawsuit. Even these settlements, however, may not have benefited the plaintiff corporation once the costs of litigating the derivative suit are taken into account.

119. See id at $1807-25$.

120. See supra notes $4-5$. 
The stock option suits in the study fared better. Unlike the settlements in the other shareholder derivative suits, the settlements in the stock option suits typically involved an agreement by the officers or directors who had received backdated stock options to return these options to the company. Specifically, defendants in $7 \mathbf{2 . 4} \%$ of the stock option settlements agreed to reprice or forfeit backdated options or disgorge any profits that they received as a result of the backdating. In short, the individual defendants had to surrender something-often stock options worth a considerable amount of money - to settle the claims filed against them.

At first glance, these settlements appear to offer meaningful deterrence. Even in these cases, however, the deterrent value is mixed. Yes, the defendants had to return their ill-gotten gains, but the sanctions were aimed at disgorgement rather than penalizing the individuals. These defendants only had to return money that they never should have had in the first place; they did not have to bear the full cost of their actions. ${ }^{121}$ Such disgorgement certainly has some deterrent value-people will not steal money if they know they will have to pay it back-but it also means that the worst that most of these defendants had to fear was that they would have to repay what they took. Despite this critique, however, there is little doubt that the stock option suits ended with far more meaningful sanctions than the other derivative suits, a point explored further in Part III.

Why do so many shareholder derivative suits end with worse outcomes than other types of corporate fraud lawsuits? The answer likely lies in a combination of two factors. First, shareholder derivative suits are often strangled by a host of procedural requirements. These requirements are all aimed at preventing frivolous derivative litigation, but their effect is to make it nearly impossible for derivative plaintiffs to present the merits of their claims. ${ }^{122}$

Second, many shareholder derivative suits may simply serve as tagalong suits to other types of corporate litigation. The data above suggest that most derivative suits today target fraud, rather than more traditional forms of selfdealing. The most common way for derivative plaintiffs to challenge alleged fraud is by alleging that the board of directors breached its duty of oversight by failing to prevent the alleged fraud. Courts have generally been skeptical of these backdoor efforts to challenge suspected fraud, largely because few plaintiffs have been able to amass the evidence to support these claims. It is

121. These costs include the expenses associated with restating financial results, payments that the corporation had to make in other litigation (such as settement payments in the securities class actions, penalties in SEC enforcement actions, etc.), the cost of internal investigations, and legal expenses.

122. These procedural hurdles include the demand requirement, the SLC process, and the contemporaneous-ownership requirement, among others. See EDWARD BRODSKY \& M. PATRICIA ADAMSKI, LAW OF CORPORATE OfFICERS AND DIRECTORS: RightS, DUTIES AND LIABIL.TTIES \$§ 9.4, $9.6,9 \cdot 23(2009)$. 
hard enough to prove fraud in the first place-it is harder still to prove that the board breached its fiduciary duties by failing to prevent the alleged fraud.

These observations provide a starting point for future reform of shareholder litigation. Corporate law scholars uniformly agree that shareholder litigation is in need of serious reform. ${ }^{123}$ The data above present a compelling case that shareholder derivative suits should be an early target of any reform efforts. Yet these efforts must take place within the larger landscape of corporate fraud litigation. Any reforms that encourage the filing of shareholder derivative suits against only the most culpable individuals would likely result in suits that simply duplicate government enforcement efforts. Similarly, reforms that allow corporations, rather than individuals, to bear the bulk of the settlement burden would encourage shareholder derivative suits that are simply tagalong suits to securities class actions and other private litigation. If shareholder derivative suits are to play a meaningful role in deterring corporate fraud, they must have a role beyond duplicating other litigation. In a world of parallel litigation, the time has come for more targeted deterrence of corporate fraud.

\section{IMPLICATIONS: TOWARD TARGETED DETERRENCE OF CORPORATE FRAUD IN SHAREHOLDER DERIVATIVE LITIGATION}

We have now seen that allegations of corporate fraud often give rise to numerous parallel lawsuits. Outside the realm of corporate law, parallel litigation serves a compensatory function-different lawsuits compensate different groups of plaintiffs. Corporate fraud lawsuits, however, typically do not serve a compensatory goal. ${ }^{124}$ Instead, legal scholars have long agreed that the chief purpose of these lawsuits is deterrence, ${ }^{125}$ a goal that makes analyzing parallel lawsuits more complicated. As appealing as it may be to throw ever more legal resources at deterring corporate fraud, it does not make sense to have multiple lawsuits aimed at the same goal of deterrence. Under the current regime, shareholder derivative suits have little marginal impact in deterring corporate fraud because these suits so closely mirror other types of litigation. This Part presents a framework for more targeted deterrence of corporate fraud, exploring opportunities for shareholder derivative suits to complement the deterrence efforts of other parallel litigation.

123. See, e.g., Lawton W. Hawkins, Exchange-Enhanced Special Litigation Committees, Enforcing Fiduciary Duties Among a Culture of Trust, 2003 UTAH L. REV. $5^{87}$ (proposing reforms for shareholder derivative suits); E. Norman Veasey \& Michael P. Dooley, The Future of Corporate Litigation in the Twenty-First Century, 25 DEL. J. CORP. L. 131, 142 (2000) (arguing that "the most likely candidate for reform on the state level is the derivative suit"); Thompson \& Thomas, supra note 13 (proposing changes to the procedural hurdles in derivative litigation).

124. See supra note 9.

125. See supra note 10. 


\section{A. PRIVATE COMPANY DISPUTES}

The first area where shareholder derivative suits can play a key role is in combating corporate fraud and other malfeasance in private companies. Most shareholder derivative suits are filed on behalf of large, public companies, ${ }^{126}$ and the findings in Part II focus on these public company suits. Yet $23 \%$ of the suits in the study were filed on behalf of private companies, ${ }^{127}$ and these suits highlight a potentially valuable role for shareholder derivative suits.

Few of the private company suits in the study were accompanied by the types of corporate fraud lawsuits examined in Part II. Only $10.5 \%$ of the private company suits involved a parallel government enforcement action or investigation. ${ }^{128}$ Similarly, only one of the private company suits was accompanied by a parallel securities class action, compared to nearly $75 \%$ of the public company suits. ${ }^{129}$

These figures, however, do not mean that the players in private companies are always less litigious. In $47.4 \%$ of the suits, there was at least one parallel lawsuit. ${ }^{30}$ Rather than filing securities class actions or government enforcement actions, however, the aggrieved victims of private company fraud typically filed more traditional lawsuits, such as breach of contract suits or direct fiduciary duty claims.

Moreover, the settlements that were presented to the court appear to be far more beneficial to the plaintiff corporations than the public company settlements discussed above. None of the private company settlements involved corporate governance reforms. Instead, the settlements were

126. As discussed in Part I, my data are limited to the federal courts. As discussed below, a higher percentage of shareholder derivative suits may be filed on behalf of private companies in state court.

127. Specifically, 38 of the 164 federal derivative suits in the study were filed on behalf of private companies.

128. It is important to note, however, that private companies are not subject to the same disclosure obligations as public companies and therefore there may have been more parallel government lawsuits or investigations that this study did not uncover.

129. This difference likely reflects the fact that the financial incentives to file these suits are far stronger in the public company context. Although the antifraud provisions in the federal securities laws apply to public and private companies alike, the damages are greater in public company suits because public companies typically have a larger market value, which leads to larger financial losses in the wake of corporate fraud.

130. As noted above, this study may also understate the level of parallel litigation in private companies. As noted above, private companies are not subject to the same disclosure requirements as public companies, and therefore there may be more parallel litigation lurking beyond the reach of litigation researchers. Additionally, there may be more private company suits filed in state court, and these data may present different conclusions. 
generally business solutions to business problems, with the parties exchanging money or stock to settle their grievances. ${ }^{131}$

The litigation involving a small Pennsylvania company called Circle of Friends $\mathrm{ADHC}$, Inc. illustrates the promise of derivative suits in private companies. This suit involved a corporate tug-of-war over Circle of Friends, a care center for senior citizens in Philadelphia. ${ }^{132}$ According to the complaint, the defendants stole money from Circle of Friends and refused to pay the plaintiffs their rightful share of the corporation's profits. ${ }^{33}$ The defendants vehemently denied the allegations, claiming that the plaintiffs were the ones who had stolen from the company.134 After two years of heated litigation, the parties agreed to a settlement in which the corporation purchased the plaintiffs' shares, allowing the parties to go their separate ways. ${ }^{135}$ The case was complicated and messy, but the derivative litigation ultimately provided a means for the parties to extricate themselves from protracted corporate combat.

It is impossible to draw definitive conclusions from Circle of Friends or the other thirty-seven private company suits in the dataset. Even this limited dataset, however, suggests that private company suits have more promise than their public company counterparts, both in compensating plaintiff corporations and in deterring future instances of corporate wrongdoing. On the compensatory side, private company disputes are more likely to involve overt misconduct-stealing from the company, usurping corporate opportunities, entering into sham transactions with the company, etc. In these instances, shareholder derivative suits may be the best way for the companies to recoup their losses. Indeed, shareholder derivative suits were traditionally designed to target this kind of self-dealing, not the fraud and other related claims that have overtaken public company derivative suits. Private company suits are also likely to be less expensive to litigate, tilting the cost-benefit analysis in favor of pursuing the suit.

Shareholder derivative suits may also have greater potential in deterring corporate malfeasance in the private company setting. As explained above in Part II, it is often quite easy for shareholders in public companies to turn derivative claims into federal securities claims and vice versa. Yet shareholders in private companies who suspect that a majority shareholder is

131. It is difficult to make conclusive findings about the private company suits because the parties in many suits failed to submit their settlement agreements to the court, as required under Rule 23.1 of the Federal Rules of Civil Procedure. See FED. R. CIV. P. 23.1.

132. Complaint 123 . Nedler v. Vaisberg, 427 F. Supp. $2 d 5_{3}$ (E.D. Pa. 2006) (No. 05-CVo6113), 2005 WL 3724465 .

133. See id. II $44-51$.

134. See Motion [to Dismiss], Nedler, 427 F. Supp. 2d 563 (No. 05-CV-6113), 2006 WL $4314^{8} 5$.

135. See Memorandum of Law in Support of Affidavit in Support of Request for Judgment of Record at 1-2, Nedler, 427 F. Supp. 2d 563 (No. 05-2976), 2009 WL 1966959. 
stealing money from the corporation or otherwise self-dealing may not always have another remedy given the specific legal requirements of other possible claims. A claim for oppression, for example, typically requires proof that the majority shareholder has frozen out the minority by withholding dividends, denying the minority a seat on the board, or other similar actions. ${ }^{136} \mathrm{~A}$ breach of contract claim requires the minority shareholder to identify a specific contractual provision that the majority shareholder has breached. A direct claim for breach of fiduciary duties requires the shareholder to establish that it was hurt in a way distinct from the corporation's injury. ${ }^{137}$ In short, derivative suits often fill a litigation void in private companies, providing a remedy for shareholders who might otherwise have no way to obtain relief.

Put simply, unlike in the public company context, the limited data on private company suits do not suggest that these suits are broken. Future research may uncover problems with these suits, either in the resolution of the suits or in the interplay between these suits and other forms of legal remedies. At this point, however, there is no pressing need for reform of private company derivative suits. Reform efforts should focus on public company suits, a topic to which we now turn.

\section{B. LITIGATION VACUUMS}

In a world of parallel litigation, what role do derivative suits play in combating fraud or other misconduct in public companies? The first possibility lies in what I have termed "litigation vacuums"-situations in which a derivative suit is the only suit, or one of the only suits, that is filed. The concerns raised in Part II apply in situations in which a derivative suit is filed along with other lawsuits, allowing the derivative suit to serve as a tagalong lawsuit rather than a meaningful source of deterrence for corporate managers. Yet there are situations in which the shareholder derivative suit stands alone, and these situations may present an opportunity for derivative suits to shine.

As we saw in Part II, most shareholder derivative suits target fraud, mirroring the allegations in other types of litigation. In theory, however, shareholder derivative suits have the potential to target corporate wrongdoing that does not sound in fraud. The classic example is a corporate officer who usurps a corporate opportunity from the company. Corporate law makes clear that such usurpation violates the officer's fiduciary duties..$^{138}$

136. Ser, e.g., Kiriakides v. Atlas Food Sys. \& Servs., Inc., 541 S.E.2d 257, 267-68 (S.C. 2001) (describing the elements of a "freeze out"). Moreover, oppression claims are not available to shareholders of Delaware corporations. See Nixon v. Blackwell, 626 A.2d 1366 , 1379-81 (Del. 1993).

137. See Tooley v. Donaldson, Lufkin, \& Jenrette, Inc., 845 A.2d 1031, 1035 (Del. 2004 ).

138. See, e.g., Beam ex rel. Martha Stewart Living Omnimedia, Inc. v. Stewart, 833 A.2d 961 (Del, Ch. 2003). 
If the corporate opportunity involved an amount of money that was not material to the company or did not involve a false or misleading statement to the market, the shareholders likely will not be able to bring a claim under the federal securities laws. In these cases, a shareholder derivative suit may be the only way to pursue legal redress. ${ }^{339}$ The same legal vacuum might result if a corporation overpays its executives or the board does not exercise proper oversight over corporate operations, if these acts are not reflected in a false or misleading statement to the market. In theory, therefore, there is a legal vacuum in which derivative suits stand alone as the only legal option for shareholders of public corporations.

Yet this theory does not match the reality of corporate litigation. As this study demonstrates, any litigation vacuum may be fairly small, at least in the federal courts. Only $5.6 \%$ of the public company suits in my sample ( 7 out of 126 suits) were unaccompanied by any parallel litigation or investigations. The seven stand-alone suits are interesting for one simple reason-none of the suits ended with a meaningful financial settlement for the company. ${ }^{14} \mathrm{O}$ Although these examples are anecdotal given their small number, they challenge the theory that the value of derivative suits lies in litigation vacuums.

On the other hand, the litigation vacuum may be larger than these figures indicate. This study focused on corporate fraud litigation in the federal courts, where parallel litigation may be more common. ${ }^{14}$ It is possible that there are more stand-alone suits in the state courts. There is little empirical data on state court derivative suits, ${ }^{1.4^{2}}$ but the data that does exist suggests that derivative suits filed in state court may play a more distinctive role in deterring corporate managers. In their study of derivative suits filed in the Delaware Court of Chancery, Randall Thomas and Robert Thompson found that approximately forty shareholder derivative suits are filed per year in Delaware state courts, ${ }^{143}$ a far smaller number than in the federal courts. ${ }^{144}$ Yet almost half of the public company Delaware suits

139. Despite the ubiquitousness of such cases in corporate law treastises, there were no corporate opportunity cases in this study that ended with a meaningful financial benefit.

140. Specifically, three of the suits were involuntarily dismissed, one suit was voluntarily dismissed, and the remaining three suits settled. None of these settlements ended with the plaintiff corporation receiving a meaningful financial benefit.

141. As discussed above, the federal courts have exclusive jurisdiction over many claims brought under the federal securities laws. Accordingly, one might expect shareholder derivative suits based on the same allegations as parallel securities class actions to be filed in federal court and stand-alone derivative suits to be filed in state court.

142. There is no state court equivalent to PACER, and therefore, state court litigation research must focus either on a single business court, such as the Delaware Court of Chancery, or published decisions available through a commercial database, such as Westlaw or Lexis. Neither source allows for a comprehensive examination of state court litigation.

143. See Thompson \& Thomas, supra note 13 , at 1762.

144. See Erickson, supra note 12, at $1761-63$. 
involved allegations of self-dealing by managers, ${ }^{145}$ allegations seen in very few of the federal suits. The Delaware suits also involved fewer indicia of frivolous litigation than the federal suits in the study. For example, the suits involved fewer filed complaints, ${ }^{4} 4^{6}$ suggesting that shareholders are not rushing to the courthouse to file identical suits, and these suits were less likely to involve a small cadre of law firms than other types of corporate litigation. ${ }^{4} 47$

Moreover, there may be partial litigation vacuums, or situations in which a shareholder derivative suit is accompanied by a smaller number of parallel lawsuits. In these instances, there may not be the maelstrom of litigation seen in many of the other cases, and the shareholder derivative suits may accordingly serve a more valuable role. The best examples in this study are the shareholder derivative suits that arose out of alleged backdating of stock options. These suits were not filed within pure litigation vacuums-more than half were accompanied by parallel securities class actions, and nearly all were accompanied by a government investigation..$^{18}$ Yet the underlying allegations have proven to be a better fit for state fiduciary duty law than other legal theories, and derivative plaintiffs have obtained a number of favorable settlements in these suits.

The derivative suit filed on behalf of Affiliated Computer Services, Inc. presents just one example of the role that shareholder derivative suits can serve when not overshadowed by other parallel litigation. ${ }^{49}$ Affiliated Computer has admitted that it backdated its stock options over an elevenyear period, allowing it to meet Wall Street's earnings estimates..$^{\circ}$ Shortly after the company made these revelations, it was hit with seven shareholder derivative suits, including four suits filed in state court and three suits filed in federal court. ${ }^{15}$ Following protracted negotiations, several individual

145. See Thompson \& Thomas, supra note 13 , at 1772.

146. See id. at 1768 ("For derivative suits against public firms, about half generated only one derivative suit per transaction and seldom were there more than two such suits.").

147. See id. (noting that the same sixteen law firms were involved in $75 \%$ of state law class actions, but only $45 \%$ of state court derivative suits).

148. See supra notes $54^{-60}$.

149. See Second Amended Derivative Complaint for Violations of the Federal Securities Laws and Supplemental State Law Claims, In re Affiliated Computer Servs. Derivative Litig., No. 3:06-cv-11 10-M (N.D. Tex. Feb. 1, 2008), 2008 WL 1880762.

150. See Affiliated Computer Servs., Inc., Current Report (Form 8-K) (Nov. 27, 2007), at ex. 99.1, available at http://www.sec.gov/Archives/edgar/data/2135/o00095013406022184/ $\mathrm{d}_{4} 1607$ exv99w1 htm.

151. See Stipulation Consolidating Cases for all Purposes, and Setting Schedule for Filing of Consolidated Complaint, Lunceford v. Rich, No. o6-cv-1212-M (N.D. Tex. Aug. 1, 2006): Order, In $n$ Affiliated Computer Servs. Derivative Litig., No. 3:06-CV-1110-M (N.D. Tex. Feb. 12, 2007): Affiliated Computer Services, Inc.'s and Defendants' Motion To Stay all Proceedings and for Expedited Consideration and Brief in Support, In re Affiliated Computer Serus., No. 3:06CV1110 (Tex. Dist. Ct. Nov. 26, 2008). There was a parallel ERISA suit, but the suit settled for only $\$ 1.5$ million, a paltry sum for a company with annual net income of more than $\$ 400$ 
defendants agreed to pay cash to the company or reprice their stock options..$^{15^{2}}$ The company also received $\$ 30$ million from the individuals' insurance carrier as part of the settlements. ${ }^{153}$ Overall, the derivative suit packed a big deterrent punch, both for the specific individuals who agreed to contribute to the settlement and for other corporate managers who may be contemplating related types of corporate wrongdoing. Many of the other stock option suits ended with similarly beneficial settlements for the plaintiff corporations. ${ }^{154}$

The stock option suits presented the perfect opportunity for shareholder derivative suits to shine. First, unlike nearly all other shareholder derivative suits, the defendants in these suits received millions of dollars to which they were unequivocally not entitled. By contrast, most shareholder derivative suits do not involve claims that the defendants personally benefited from their actions in such a clear and direct way. Second, the facts often did not support claims under the federal securities law. Many shareholders did file securities class actions against companies that backdated stock options, but these shareholders often could not establish loss causation or other legal requirements of a fraud claim..$^{155}$ The fiduciary duty claims were a better fit for the underlying facts than causes of action that sounded purely in fraud because the core problem was bad acts, not bad disclosures.

In the end, however, these litigation vacuums may be few and far between. Stock option suits are a nearly unparalleled example of how derivative suits can shine among the wide array of enforcement alternatives. There were no other examples of such suits in this study, and it is difficult to

million. See Amended Notice of Class Action Settlement, Settlement Fairness Hearing, and Motion for Attorneys Fees and Reimbursement of Attorney Expenses at 1, In re Affiliated Computer Servs. ERISA Litig., No. 3:06-CV-1592-M (N.D. Tex. July 17, 2008), available at http://www.ssbny.com/acsnotice.pdf. Affiliated Computer Services was not named in a securities class action.

152. See Lead Plaintiffs' Memorandum of Law in Support of Motion for Final Approval of Proposed Derivative Settlement Under Federal Rule of Civil Procedure 23.1 at 10, In re A/filiated Computer Servs., No. 3:06-cv-1110 (N.D. Tex. June 12, 2009), 2009 WL 2821188.

153. Id. at 4 \& n.2.

154. See, eg., Report of the Special Litigation Committee at 74-75, In re UnitedHealth Grp. Inc. S'holder Derivative Litig., 631 F. Supp. 2d 1151 (D. Minn. 20o9) (No. o6-CV-1216-JMRFLN), 2007 WL 4298730 (describing settlement valued at approximately \$9oo million); Stipulation and Agreement of Partial Settlement at 11-13, In re Broadcom Corp. Derivative Litig., No. CVo6-3252 R (CWx) (C.D. Cal. Aug., 28, 2009) (discussing a settlement that included a $\$ 118$ million payment to the corporation from its D\&O insurance policy, as well as repriced or forfeited options from several individual defendants); Stipulation of Settlement at 12-13, In re Juniper Derivative Actions, No. 5:06-cv-03396-JW (N.D. Cal. Aug. 26, 2008) (discussing a settlement that included repriced or forfeited options with a value of approximately $\$ 22.7$ million).

155. See, e.g., In re Maxim Integrated Prods., Inc. Sec. Litig., 639 F. Supp. $2 d 1038$ (N.D. Cal. 2009) (dismissing securities class action because the plaintiff failed to allege loss causation related to the alleged backdating). 
think of other recent examples outside of the period covered by the study. As the data in Part II make clear, few derivative suits succeed where other suits fail. ${ }^{13^{6}}$ It is far more typical for corporate malfeasance to spark numerous parallel lawsuits, of which the shareholder derivative suit is typically the least successful. The stock option suits, however, do highlight the potential value of shareholder derivative suits in that sliver of legal space in which other potential plaintiffs turn away. The question then becomes whether shareholder derivative suits can add value outside of these rare litigation vacuums.

\section{THE CASE OF CORPORATE OUTSIDERS}

If legal vacuums are an aberration, what role can shareholder derivative suits play in the more common situation in which these suits are filed in concert with other types of corporate fraud litigation? The greatest potential for shareholder derivative suits may lie in their ability to deter outside directors.

As explained in Part II, shareholder derivative suits are the only type of corporate fraud lawsuit that routinely targets outside directors. These findings likely reflect strategic concerns unique to shareholder derivative suits. State law mandates that shareholders make a presuit demand on the plaintiff corporation's board unless such a demand would be futile. ${ }^{157}$ One of the most common ways for a shareholder to plead futility is to allege that the board itself faces a significant risk of liability in the suit and therefore would be unlikely to authorize the corporation to file suit. This procedural requirement leads to plaintiffs' attorneys targeting outside directors and then claiming that demand is excused because the outside directors cannot conduct an unbiased review of the litigation..$^{15^{8}}$ This requirement creates

156. I do not want to imply that the stock option suits are the only examples of successful derivative suits. This study included a small number of other such suits, and 1 can identify at least a few examples outside of the time period covered by the study. See, e.g., Stipulation of Settlement at $2-7,14$. Teachers' Ret. Sys. of La. v. Greenberg, No. 201o6-VCS (Del. Ch. Sept. 30,2008 ) (discussing a $\$ 115$ million settlement in a shareholder derivative suit alleging selfdealing, of which approximately $\$ 29.5$ million was paid by the individual defendants); Notice of Pendency of Proposed Settlement of Derivative Actions at 4, In re Cardinal Health Derivative Litig., No. 02-CVG-11-0639 (Ohio Ct. C.P. Oct., 2007), available at http://www.gilardi.com/ pdf/cdnldernot.pdf (discussing a \$7o million settlement in a shareholder derivative suit alleging accounting misstatements related to reserves, revenue recognition, and other earnings management practices). My point is that such suits are the exception, while most derivative suits filed in federal court follow the pattern identified in this study, duplicating the allegations in other lawsuits and ending with far less impressive outcomes.

157. In re Citigroup Inc. S'holder Derivative Litig., 964 A.2d 106, 120 (Del. Ch. 2009).

15. Additionally, the legal standards in other types of claims make it difficult for securities plaintiffs to target outside directors. For example, a plaintiff seeking to prevail on a federal securities claim must allege facts creating a strong inference that the defendant acted with scienter, or intent to deceive. See Tellabs, Inc, v. Makor Issues \& Rights, Ltd., $55^{1}$ U.S. 308, 325 $(2007)$. It is difficult enough for securities plaintiffs to survive this hurdle in claims against 
incentives for derivative plaintiffs to sue outside directors, 159 incentives that do not exist in other types of corporate fraud lawsuits.

Moreover, even when outside directors are named in these other lawsuits, they almost never have to make a financial payment, which undercuts the deterrent value of these suits. ${ }^{160}$ As a number of studies have demonstrated (including this one), outside directors enjoy a de facto immunity at the settlement table. This immunity reflects the fact that outside directors are typically sued along with corporations, and these corporations are often willing to pay the entire settlement amount to end the litigation. Shareholder derivative suits are different because the corporation is the plaintiff, and therefore individuals cannot hide behind a corporate defendant. By isolating individuals from their corporate employers, shareholder derivative suits have the potential to offer greater deterrence.

Yet shareholder derivative suits are not exploiting this opportunity. As the figures in Part II demonstrate, outside directors rarely contribute financially in shareholder derivative suits. They may be more involved with the day-to-day litigation decisions, but at the end of the day, they are rarely required to make the hard financial sacrifices that lead to meaningful deterrence. In short, there is a gap between the promise and payoff of derivative suits.

The reason for this gap likely lies in corporate law's ambivalence regarding the legal liability of outside directors. Corporate law maintains several theories of liability against outside directors, but makes it nearly impossible for shareholders to hold outside directors liable under any of these theories. This ambivalence is evident in the recent case law illuminating the duty of good faith, which is the primary way in which shareholders seek to hold outside directors liable in a shareholder derivative suit.

officers who were involved in the day-to-day management of the business. It is far more difficult to allege such facts against outside directors who have less knowledge over the inner workings of the business.

159. Shareholders cannot avoid the demand requirement simply by naming the board in the suit. Instead, "demand will be excused based on a possibility of personal director liability only in the rare case when a plaintiff is able to show director conduct that is 'so egregious on its face that board approval cannot meet the test of business judgment, and a substantial likelihood of director liability therefore exists." In re Citigroup, 964 A.2d at 121 (quoting Aronson v. Lewis, 473 A.2d 805,815 (Del. 1984), overnuled in part on other grounds by Brehm v. Eisner, 746 A.2d 244 (Del. 2000)).

160. See supra notes $115^{-18}$ and accompanying text. A study by Bernard Black, Brian Cheffins, and Michael Klausner, for example, concluded that outside directors have a significant risk of personal liability only in those "perfect storm" scenarios in which (i) the company is insolvent and has insufficient insurance coverage, (ii) the case involves an unusually strong claim, and (iii) the outside directors are both wealthy and culpable. Bernard Black et al., Outside Director Liability, 58 STAN. L. REV. 1055, 1060-61 (2006). 
In the 2006 decision of Stone v. Ritter, the Delaware Supreme Court addressed the role of good faith in Delaware corporate law. ${ }^{161}$ The court upheld the continued vitality of the duty of good faith, holding that it was part of the duty of loyalty. ${ }^{16 z}$ In the (admittedly small) hierarchy of fiduciary duties, the duty of loyalty is the most important. ${ }^{163}$ Corporate managers who violate the duty of loyalty are viewed as more deserving of shame than those who violate the duty of care or other legal obligations. Standing alone, therefore, this part of the opinion reinforced the need to hold outside directors accountable.

Yet what the Delaware Supreme Court gave with one hand it took away with the other. The court went on to emphasize the steep hurdles shareholders face in attempting to establish a breach of the duty of good faith. The court held that shareholders can only establish a violation of the duty of good faith by proving that "(a) the directors utterly failed to implement any reporting or information system or controls; or (b) having implemented such a system or controls, consciously failed to monitor or oversee its operations." ${ }^{164}$ The court ended the opinion by warning shareholders that the duty of good faith is "possibly the most difficult theory in corporation law upon which a plaintiff might hope to win a judgment." ${ }^{16_{5}}$ Putting these two halves of the opinion together, the Delaware Supreme Court maintained the possibility of liability for outside directors but made it extremely difficult for shareholders to establish such liability.

The Stone decision is only one example of a sweeping jurisprudence that protects corporate directors from liability. ${ }^{166}$ The result of these decisions is that outside directors face almost no risk of liability under state law. Indeed, as Professor Lynn Stout has argued, "it is only a slight exaggeration to suggest that a corporate director is statistically more likely to be attacked by killer bees than she is ... to ever pay damages" in a fiduciary duty suit. ${ }^{167}$ In short, courts want to deter corporate directors, just not very much.

\footnotetext{
161. See Stone v. Ritter, 911 A.2d 362 (Del. 2006).

162. See id. at $369-70$.

163. See Stephen M. Bainbridge et al., The Convergence of Good Faith and Oversight, 55 UCLA
} L. REV. 559. 568 (2008) ("Breach of a director's duty of loyalty thus long has been recognized as differing in kind and not just in degree from a violation of the fiduciary duty of care.").

164. Stone, 911 A.2d at 370 (first and third emphases added).

165. Id. at 372 (quoting In re Caremark Int'l Inc. Derivative Litig., 698 A.2d 959, 967 (Del. Ch. 1996)) (internal quotation marks omitted).

166. See, e.g., In re Citigroup Inc. S'holder Derivative Litig., 964 A.2d 106 (Del. Ch. 2oog) (granting a motion to dismiss filed by outside directors relating to their alleged failure to protect Citigroup from risks in the subprime lending market); In re Caremark, 698 A.2d 959 . $970-71$ (holding that a claim that directors failed to prevent the company from violating federal anti-kickback laws "quite likely [was] susceptible to a motion to dismiss").

167. Lynn A. Stout, On the Proper Motives of Corporate Directors (or, Why You Don't Want To Invite Homo Economicus To Join Your Board), 28 DEL.. J. CORP. L. 1,7 (2003). 
The point is not that the Delaware Supreme Court should have defined the duties of outside directors more broadly. Just because there is a hole in the law does not mean that we should rush to fill it. There are good reasons for courts to protect outside directors. A limited liability standard encourages directors to take more risks in the boardroom, and this risk taking generally benefits shareholders. ${ }^{168}$ If outside directors were subject to greater liability, they would naturally become more risk-averse because they would be bearing more of the risk of their decisions without experiencing more of the benefits. ${ }^{169}$ Alternatively, outside directors might decide that the risks outweigh the benefits and decide not to serve on corporate boards. Accordingly, it may well make sense for the courts to enforce only a minimal liability standard for directors.

Yet the fact remains that it is incredibly difficult to hold outside directors liable for breaching their fiduciary duties. This point highlights the irony of shareholder derivative suits. When viewed through the lens of parallel litigation, shareholder derivative suits appear poised to play a meaningful role in deterring corporate directors, a role that other types of corporate litigation do not play. Yet the substantive law in shareholder derivative suits undercuts this deterrence function. Indeed, the substantive law may reinforce the idea that derivative suits are frivolous. It is extremely difficult for shareholders to allege a viable claim, so most claims inevitably fall short, which in turn bolsters the belief that these suits lack merit.

Granted, shareholder derivative suits may have deterrent value even if these suits do not result in meaningful sanctions..$^{17^{\circ}}$ People presumably do not like to be sued, and they may refrain from violating the law simply to avoid the social stigma of being named as a defendant in a lawsuit even if they do not fear serious penalties in the suit. ${ }^{17}$ This may be especially true for high-level corporate executives, who may be even more concerned with protecting their reputations. Yet existing scholarship suggests that any such

168. Donald E. Pease, Outside Directors: Their Importance to the Corporation and Protection from Liability, 12 DEL. J. CORP. L. 25. 95 (1987) ("Directors should not be so apprehensive about possible legal liability for their decisions that they will take little or no risk or innovative action in the boardroom. If directors spend most of their time building paper trails in order to assure the successful defense of lawsuits, the ingenuity of our system will diminish."). There are other reasons for this deference to outside directors as well. See, e.g., Stephen M. Bainbridge, The Business Judgment Rule as Abstention Doctrine, 57 VAND. L. REv. $8_{3}, 117-27$ (2004).

169. This same rationale underlies the business judgment rule. See, e.g., Gagliardi v. Trifoods Int'l, Inc., 683 A.2d 1049, $105^{1-52}$ (Del. Ch. 1996).

17o. Alternatively, outside directors may not know the small likelihood of being found liable for breaching their fiduciary duties. In other words, deterrence may result not from the law itself, but from a misapprehension of the law. See, e.g., Ehud Kamar, Shareholder Litigation Under Indeterminate Conporate Law, 66 U. CHI. L. REV. 887 (1999) (arguing that uncertainty in corporate law leads corporate managers to decisions that are not socially optimal and exposes managers to socially costly sanctions).

171. See David A. Skeel, Jr., Shaming in Corporate Law, 149 U. PA. L. REV. 1811,1812 (2001). 
stigma may be relatively weak. ${ }^{172}$ A director only suffers a stigma if there is social shame associated with being named as a defendant in a lawsuit. ${ }^{173}$ Directors will not experience social shame if there is a widespread belief that the litigation in question is frivolous. ${ }^{174}$ Given the unimpressive sanctions in most shareholder derivative suits, many directors may view being named as a defendant as a sign of bad luck rather than bad performance.

This critique highlights the difficulties in reforming derivative suits. As the previous two sections demonstrate, there are two key areas in which shareholder derivative suits can add value in a world of parallel litigation. The first area is in litigation vacuums in which shareholder derivative suits are among the only suits that are filed. Yet these vacuums are few and far between, at least in the federal courts. Moreover, other than the atypical example of stock option suits, most litigation vacuums are not places where shareholder derivative suits earn their keep. The second promising area is in deterring corporate directors. Yet as we have just seen, the substantive law works hard to avoid imposing personal liability on outside directors in all but the most egregious cases.

Perhaps the greatest potential for shareholder derivative suits lies beyond their limited ability to deter corporate wrongdoing. The discussion now turns to this final possibility in the search to find value in shareholder derivative suits within the parallel world of corporate fraud litigation.

\section{THE ROLE OF CORPORATE NORMS}

Can shareholder derivative suits add value even if they do little to compensate corporations or deter individual wrongdoers? Before writing off shareholder derivative suits entirely, we must analyze the way in which these suits influence board decision-making, an analysis that goes beyond the traditional framework of compensation and deterrence.

Over the last several years, scholars have developed a robust theory of the role of norms in corporate law. ${ }^{75}$. Underlying this theory is the idea that litigation may have value even if the victims are never compensated and the wrongdoers never punished. In its simplest form, norms theory recognizes

172. Ser, e.g., Renee M. Jones, Law, Norms, and the Breakdoun of the Board: Promoting Accountability in Corporate Governance, 92 IOWA L. REV. 105 (2006); Stout, supra note 167 , at 7.

173. See, e.g., James D. Cox, The Social Meaning of Shareholder Suits, 65 BROOK. L. REV. 3, 5 (1999).

174. Secid.

175. Ser, e.g., Melvin A. Eisenberg. Corporate Law and Social Norms, 99 Colum. L. REV, 1253. 1264-88 (1999): Marcel Kahan, The Limited Significance of Norms for Conporate Governance, 149 U. PA. L. REV. 1869 (2001): Edward B. Rock, Saints and Sinners: How Does Delaware Corporate Law Work?, 44 UCLA L. REV. $1009,1072-1105$ (1997): Edward B. Rock \& Michael L. Wachter, Islands of Conscious Power: Law, Norms, and the Self-Governing Corporation, 149 U. PA. L. REV. 1619. $1663-94$ (2001). 
that informal rules can influence an individual's behavior, ${ }^{176}$ even if such rules are not enforceable in a court of law. ${ }^{177}$ Just as societal norms encourage property owners to cooperate with their neighbors, ${ }^{178}$ corporate norms encourage managers to do a good job for the companies they serve. Corporate law tells these managers how to act, and most managers comply with these rules even if the law provides no realistic enforcement mechanism. ${ }^{179}$

Outside directors are particularly susceptible to corporate norms. CEOs or other top corporate executives may be tempted to disregard norms when faced with the possibility of significant monetary reward. ${ }^{180}$ In contrast, outside directors rarely have the opportunity to get rich through their board service. ${ }^{181}$ Board members are unlikely to see their financial futures rise or fall based on how they vote on a corporate transaction. As a result, norms theory predicts that most corporate directors will simply try to do their best in the boardroom. ${ }^{182}$ Norms articulated through litigation help directors give concrete meaning to this aspiration.

Yet the parallel world of corporate fraud litigation demands a more nuanced view of the role of law in creating corporate norms. Just as not all litigation is created equal when it comes to punishing fraud, not all litigation is created equal when it comes to creating norms. Securities class actions and SEC enforcement suits target false and misleading statements-these suits are about lies, not bad governance decisions. ${ }^{18_{3}}$ This focus means that securities class actions and SEC enforcement suits have little impact in creating the norms that tell corporate managers how to behave, except that

176. I am defining norms here to include rules or customs that are not enforced by legal sanctions. This definition includes legal rules in which there is a theoretical threat of legal enforcement, but as in derivative suits, this threat rarely occurs in practice.

177. Norms theory recognizes two types of motivation to comply with norms. Some scholars argue that managers generally comply with social norms to avoid social sanctions, such as shaming. ostracism, or embarrassment. See Rock \& Wachter, supra note 175 , at 1641 . Other scholars have argued that social norms appeal to managers' sense of altruism and desire to help others. See Margaret M. Blair \& Lynn A. Stout, Trust, Trustworthiness, and the Behavioral Foundations of Corporate Law, 149 U. PA. L. REV. 1735, 1809-10 (2001).

178. See generally ROBERT C. Ellickson, ORder Without LAW: HOW Neighbors SETtLE. DISPUTES (1991) (examining the informal norms that govern how property owners in Shasta County, California, resolved property disputes).

179. Eisenberg, supra note 175 , at 1269.

180. Rock, supra note 175 , at 1104 .

181. See id.

182. As many scholars have recognized, norms theory is often incomplete, and its application here is no different. Outside directors may be motivated by a host of incentives other than the promise of significant financial reward, and these incentives may cause them to disregard the best interests of the corporation. Indeed, the lack of financial incentives may mean that outside directors do not have enough at stake to learn the complex intricacies of the businesses they serve or the complex norms articulated through litigation.

183. See Santa Fe Indus., Inc. v. Green, 430 U.S. $462,479-80$ (1977) (holding that the federal securities laws do not create a cause of action for breach of fiduciary duty). 
they should not lie. In contrast, shareholder derivative suits go to the heart of how corporate boards make decisions-how they should determine executive compensation, how they should evaluate risk, and how they should shape corporate strategy. Within the parallel world of corporate fraud litigation, shareholder derivative suits are the only suits that directly target board decision-making. ${ }^{18_{4}}$ Accordingly, these suits have the greatest potential to shape corporate norms.

To understand the point, consider two of the most famous shareholder derivative suits from the last twenty years-In re Caremark International Inc. Derivative Litigation'85 and In re Walt Disney Company Derivative Litigation. ${ }^{186}$ Both cases ended with outcomes that would hardly qualify as successes, yet these cases have had a profound impact in shaping board behavior.

Caremark began with a run-of-the-mill fiduciary duty claim that arose out of numerous federal and state investigations into whether the company was providing illegal kickbacks to doctors. ${ }^{187}$ Shareholder plaintiffs in three sets of derivative suits alleged that the Caremark board breached its fiduciary duties by failing to provide proper oversight over the employees who orchestrated the kickbacks. ${ }^{188}$ After nearly two years of litigation, the derivative suits settled. ${ }^{189}$ The settlement included numerous cosmetic corporate governance reforms but no money for the plaintiff corporation and no sanctions against the individual wrongdoers. ${ }^{190}$ The reviewing judge, Chancellor Allen, concluded that the "changes in corporate practice that are presented as consideration for the settlement do not impress one as very significant." 19 ' Nonetheless, the chancellor approved the minimal settlement because "the record supplies essentially no evidence that the director defendants were guilty of a sustained failure to exercise their oversight function." $19 z$ In short, the suit was like so many other derivative suitsfrivolous, expensive, and largely duplicative of other litigation.

The decision might have disappeared into the annals of corporate law had Chancellor Allen not decided to use it as an opportunity to clarify the duty of oversight in Delaware corporate law. His analysis, which was subsequently adopted by the Delaware Supreme Court, ${ }^{193}$ developed a

184. Acquisition-oriented class actions may play a similar role in developing norms relevant to corporate mergers. See Robert B. Thompson \& Randall S. Thomas, The New Look of Shareholder Litigation: Acquisition-Oriented Class Actions, 57 VAND. L. REV. 133, 167-68 (2004) (analyzing the rise of acquisition-oriented shareholder class actions).

185. In re Caremark Int'1 Inc. Derivative Litig., 698 A.2d 959 (Del. Ch. 1996).

186. In re Walt Disney Co. Derivative Litig., 906 A.2d 27 (Del. 2006).

187. In re Caremark, 698 A.2d at $961-62$.

188. See id. at 964 .

189. See id. at $965-66$.

19o. Sec id. at 966 .

191. Id. at 970 .

192. Id. at 971 .

193. See Stone v. Ritter, 911 A.2d 362. 369-7o (Del. 20o6). 
comprehensive framework for oversight claims. Although Chancellor Allen stressed the hurdles shareholders face in alleging a viable claim, he also outlined an aspirational framework of best practices for corporate boards, exhorting boards to develop information and reporting systems that would bring troublesome facts within the company to their attention. ${ }^{194}$ This framework is now a standard part of board training programs and forms the basis of many compliance and oversight systems. ${ }^{195}$ Despite the lackluster ending of the litigation itself, the decision lives on as one of the most influential decisions in corporate law. ${ }^{196}$

One can tell a similar story about the Disney litigation. ${ }^{197}$ Disney arose out of the short-lived tenure of Michael Ovitz as the president of the Walt Disney Company. Under the terms of his employment agreement, Ovitz was entitled to a $\$ 140$ million payment when he was fired just thirteen months after starting at the company, a payment that Disney's shareholders challenged as grossly excessive. ${ }^{198}$ Following a lengthy trial, the court ruled in favor of Disney. ${ }^{199}$ The court held that the board did not breach its fiduciary duties in approving the severance package because of the perceived importance of Ovitz to the company and the fact that Ovitz walked away from approximately the same amount of money at his former employer when he agreed to join Disney. ${ }^{200}$

On appeal, the Delaware Supreme Court agreed with the trial court. According to the court, the shareholders' claims failed under any definition of good faith, a conclusion that could have ended the court's analysis and left the case as just one more example of an unsuccessful derivative suit. ${ }^{201}$ The court went on to explain, however, that "the duty to act in good faith has played a prominent role [in corporate law], yet to date is not a well-

194. See In re Caremark, 698 A.2d at 971 (holding that "a director's obligation includes a duty to attempt in good faith to assure that a corporate information and reporting system, which the board concludes is adequate, exists").

195. See, e.g. Claire A. Hill \& Brett H. McDonnell, Stone v. Ritter and the Expanding Duty of Loyalty. 76 FORDHAM L. REV. $1769,1795(2007)$ (noting that "the rush to abide by 'Caremark duties' after the case was decided" was leading to "[c]orporations employ[ing] well-paid advisers to tell them how to avoid conduct that might trigger liability"); E. Norman Veasey, Weil Briefing: Corporate Governance-Delauare Supreme Court Affirms Chancellor's Judgment of No Liability for Directors in Ovitz Case, in CORPORATE GOVERNANCE 2007: COUNSEl. 2007 Proxy SEAsON 155 (PL.I Corp. Law \& Practice, Course Handbook Ser. No. 10874, 2007), available at 1581 PLI/Corp 155 (Westlaw).

196. See Miriam Hechler Baer, Governing Corporate Compliance, 5o B.C. L. REv. 949, 967 (2009); Hillary A. Sale, Monitoning Caremark's Good Faith, 32 DEL. J. CoRP. L. 719, 723 (2007) ("The good-faith obligation of directors ... has received considerable scrutiny from academics, practitioners, and the courts." (footnotes omitted)).

197. In re Walt Disney Co. Derivative Litig., go6 A.2d 27 (Del. 20o6).

198. Id. at 35 .

199. See id.

200. See id. at 42 .

201. See id. at 63 . 
developed area of our corporate fiduciary duty law." ${ }^{\circ 0 z}$ The court then spent several pages of dicta developing a framework for the duty of good faith. The court also took the time to explain that even though the Disney board did not breach its fiduciary duties, it also did not comply with best practices, and the court clarified what best practices require in the context of executive compensation. ${ }^{20}$

Like the Caremark decision, this decision has become a landmark in Delaware corporate law. In the wake of Disney, corporate boards have increasingly hired compensation experts, not necessarily because they fear liability, but because such experts have become an established part of corporate best practices. ${ }^{204}$ Most boards now conduct a systematic review of possible outcomes under executive compensation contracts to ensure that board members understand the true value of stock options and other variable benefits. Caremark and Disney are perhaps the best examples of how shareholder derivative suits can shape corporate norms, but even less wellknown suits can have an incremental effect in changing the way that corporate boards make decisions.

This analysis suggests that shareholder derivative suits may have more value as written blueprints for board decision-making than as enforcement mechanisms. Yet if shareholder derivative suits are worth little more than the paper they are written on, is this enough? This topic has yet to be fully explored in corporate law scholarship, but it is worth asking whether institutional shareholders or board organizations could fill this role with less tax on corporate and judicial coffers. ${ }^{205}$ For example, many large institutional investors have adopted extensive corporate governance guidelines. ${ }^{206}$ These guidelines provide standards for the independence of board members, ${ }^{207}$ board evaluation of key officers, ${ }^{208}$ executive

202. Serid.

203. See id. at 56.

204. Cf. Lawrence A. Hammermesh, Twenty Years After Smith v. Van Gorkom: An Essay on the Limit of Civil Liability of Corporate Directors and the Role of Shareholder Inspection Rights, 45 WASHBURN L.J. 283, 284 (2006) ("[T]he Disney case itself has illustrated [that] the civil liability system, by providing a forum for intense public inspection of the content of director action, has had a salutary effect on the development of corporate governance standards by eliciting useful director attention.").

205. See Mark J. Roe, Delaware's Competition, 117 HaRv. L. REv. 588, 622 (2003).

206. See, eg., The Gal. PUb. Emps.' Ret. SYS., Global. Principles of Accountable Corp. GOVERNANCE (2010), available at http://www.calpers-governance.org/docs-sof/principles/ 2010-5-2-global-principles-of-accountable-corp-gov.pdf [hereinafter CALPERS GUIDELINES]: OHIO PUB. EMPS. REt. SYS., Proxy VOTING GUIDElines (2010), available at https://www.opers. org/pdf/governance/proxy-voting-guidelines.pdf [hereinafter OHo GUIDEL.INEs]; Proxy Voting Policies, T. ROWE PRICE, http://corporate.troweprice.com/ccw/home/ourCompany/ proxyVotingPolicies.do (last visited Aug. 27, 2011) [hereinafter T. Rowe Price Guidelines].

207. Sa CAlPERS GUIDELINES, supra note 206, $\$$ i; OHo GUIDELINES, supra note 2o6, at 3;

T. Rowe Price Guidelines, supra note 206.

208. See CALPERS GUIDELINES, supra note $206, \$ 2.8$; OHo GUIDELINES, supra note 206 , at 4 . 
compensation, ${ }^{209}$ and many other issues that boards face on a regular basis. These institutions have then attempted to enforce these guidelines through voting efforts, shareholder proposals, and other similar campaigns. ${ }^{210}$

Yet outsourcing the production of corporate norms could also dilute the effectiveness of these norms. Board members, as well as their legal advisors, may listen to the courts more than other social actors. Courts have an imprimatur of legitimacy that comes from being an independent yet educated observer of corporate disputes. The judiciary also has the threat, however miniscule, of legal liability in those rare instances in which board members blatantly disregard their duties. Other institutions lack this rare combination of stature and sanction.

This combination of traits also raises important questions about institutional competence. Should courts be in the business of setting best practices for the business world? It is one thing for courts to establish liability standards; it is quite another for courts to set aspirational standards for corporate America. This concern has traditionally been alleviated by the fact that Delaware courts enjoy a high degree of confidence among business leaders and corporate lawyers. Delaware has long been known for appointing judges with a canny business sense, and in many instances, Delaware courts have proven to be more flexible than political institutions in responding to ever-changing corporate governance demands. ${ }^{211}$ As more litigation leaves Delaware for the federal courts, however, it is important to ask whether other courts are equipped to fill Delaware's big shoes. Indeed, the judiciary's role in setting corporate norms may well recede as corporate litigation increasingly moves outside of Delaware.

The final question is the cost of developing these norms. This Article focuses on a comparative analysis of the benefits of corporate fraud litigation. Yet shareholder derivative suits impose steep costs on the litigants and judicial system alike, and a final verdict on these suits depends on both costs and benefits. Anecdotal evidence suggests that the costs can be substantial. In the derivative suit filed on behalf of Affiliated Computer Services described above, for example, the company estimated that its litigation costs were between $\$_{5}-8$ million per month. ${ }^{212}$ Run-of-the-mill derivative suits

209. See CALPERS GUIDEIINES, supra note $206, \$_{3}$; OHIO GUIDELINES, supra note 206 , at 911; T. Rowe Price Guidelines, supra note 206.

210. See, e.g., InStitutional. S'holder SERVS. INC., U.S. Corporate Governance POl.icy 2011 UPDATES (2010), available at http://www.issgovernance.com/files/ISS2011USPolicy Updates20101119.pdf (setting out corporate governance policies that inform ISS proxy voting recommendations, which are followed by a significant number of institutional investors).

211. See Marcel Kahan \& Edward Rock, Symbiotic Federalism and the Structure of Corporate Law, 58 VAND. L. REV. $1573,1598-99$ (2005).

212. See Affiliated Computer Services, Inc.'s Unopposed Motion for Final Approval of Settlement and Brief in Support at 6, In re Affiliated Computer Servs. Derivative Litig., No. 3:o6CV-1110-O (N.D. Tex. June 12, 2009). 
likely involve far smaller costs but may also have commensurably less value in deterring fraud or shaping corporate norms. ${ }^{213}$

In the end, shareholder derivative suits represent the search for a needle in a haystack. The needle may be the egregious case of corporate misconduct that falls through the cracks of other types of corporate fraud litigation, or it may be the rare case that inspires the court to write a decision that will shape boardroom practice for years to come. As the data make clear, however, the vast majority of shareholder derivative suits do not fall into either of these categories. Within the haystack of corporate fraud litigation lies a significant number of shareholder derivative suits that neither compensate corporations nor deter corporate fraud. The question corporate law must confront is whether the needles are worth the haystack.

\section{CONCLUSION}

Conventional wisdom holds that more litigation is better when it comes to combating corporate fraud. As this study demonstrates, however, this wisdom does not reflect the modern reality of corporate fraud litigation. The study reveals a world of parallel litigation in which the same allegations of corporate misconduct often lead to different lawsuits based on different legal theories. These findings raise critical questions about traditional theories of deterrence in corporate law. Scholars have long assumed that different types of corporate litigation offer different avenues for deterring the masterminds of corporate fraud. Yet parallel corporate fraud litigation often targets the same underlying misconduct, leaving other conduct beyond the law's reach.

The tremendous upheaval in the financial markets gives renewed importance to efforts to deter corporate fraud. The time has come to bring these new empirical insights to bear in reforming corporate fraud litigation. Understanding the role of parallel litigation is critical to these efforts, raising key questions that have long gone unexplored in corporate law scholarship. Can we reform parallel litigation to ensure that different types of litigation work in harmony to deter corporate fraud? Is the current panoply of litigation options necessary to achieve optimal deterrence? These issues remain for another day, but one thing is clear. The time has come for more targeted deterrence of corporate fraud.

213. It is likely that the costs of shareholder derivative suits pale in comparison to the costs of other types of corporate fraud lawsuits. If a shareholder derivative suit simply mirrors the allegations in other types of litigation, the parties may not need to pay lawyers to reinvent the wheel. Given the low marginal value of derivative suits, however, even relatively low expenses present difficult choices for courts and policymakers. 
APPENDIX

This Appendix defines the variables used in the probit regression models in Part II above. The first six variables were used as dependent variables in the relevant models, while the remaining variables were used as independent variables.

\section{Table A1. Variable Definitions}

Variable

Securitiesclassaction

Erisasuit

Seccompany

Secindividuals

Criminalcompany

Criminalindividuals

Stockoptions
Indicator variable equal to one if there was a parallel securities class action based on the same events alleged in the shareholder derivative lawsuit.

Indicator variable equal to one if there was a parallel ERISA class action based on the same events alleged in the shareholder derivative lawsuit.

Indicator variable equal to one if there was a parallel SEC lawsuit or investigation targeting the corporation named in the shareholder derivative lawsuit.

Indicator variable equal to one if there was a parallel SEC lawsuit targeting the individual defendants in the shareholder derivative lawsuit.

Indicator variable equal to one if there was a parallel criminal lawsuit or investigation targeting the corporation named in the shareholder derivative lawsuit.

Indicator variable equal to one if there was a parallel criminal lawsuit targeting the individual defendants in the shareholder derivative lawsuit.

Indicator variable equal to one if the derivative plaintiff alleged the backdating of stock options. 
Industryfin

Restatement

Accountingerrors

Falsestatements

Failuretosupervise

Section1oor14

Insidertrading

Nonderivative

Marketcap

Numberofderivativesuits
Indicator variable equal to one if the target corporation was in the financial industry.

Indicator variable equal to one if the target corporation restated its financial results as a result of the events alleged in the litigation.

Indicator variable equal to one if the derivative plaintiff alleged that the target corporation made errors in the reporting of its financial results.

Indicator variable equal to one if the derivative plaintiff alleged that the target corporation made false or misleading statements to its investors.

Indicator variable equal to one if the derivative plaintiff alleged that the board of directors of the target corporation failed to adequately supervise company affairs.

Indicator variable equal to one if the derivative plaintiff alleged that the target corporation violated section 10 (b) or section 14 (a) of the Securities Exchange Act of 1934 .

Indicator variable equal to one if the derivative plaintiff alleged that the individual defendants engaged in insider trading.

Indicator variable equal to one if the derivative complaint also included nonderivative claims.

The log of market capitalization of the target corporation at the time that the derivative suit was filed.

The number of shareholder derivative suits filed, regardless of whether these suits were consolidated. 